\title{
Edmund Bojanowski jako badacz historii regionu
}

\section{Wprowadzenie}

$\bigvee \begin{gathered}\text { okresie swojej młodości Edmund Bojanowski miał kilkunastoletni } \\ \text { okres żywego zainteresowania literaturą i nauką, który poświadczony }\end{gathered}$ jest kilkoma publikacjami. Przez wiele lat ten literacko-naukowy dorobek był zapomniany. Jednak wraz z coraz szerszą popularyzacją postaci kandydata na ołtarze odkryto wartość jego prac. Największe zasługi w tym kontekście przypisać należy prof. Bogdanowi Zakrzewskiemu. Opublikowano też wiele opracowań na temat twórczości literackiej i działalności wydawniczej Bojanowskiego, jego dorobku w zakresie dialektologii, paremiografii, folklorystyki. Pomijając już to, że w większości są to krótkie, szczegółowe rozprawy rozproszone w wielu czasopismach, należy zauważyć, że nie zwrócono dotychczas większej uwagi na dorobek Bojanowskiego w zakresie historycznych badań regionalnych ${ }^{1}$. Był on tymczasem niebagatelny i pozwala uznać Bojanowskiego za prekursora regionalnych badań historycznych, dotyczących ziemi gostyńskiej. Przekonanie to nie może się jednak przebić do powszechniej świadomości większości badaczy, głównie za sprawą anonimowego opublikowania jednego z podstawowych tekstów E. Bojanowskiego na ten temat. Dzieje się tak pomimo tego, że autorstwo Bojanowskiego zostało stwierdzone i udowodnione.

\footnotetext{
* Łukasz Puślecki - doktor nauk humanistycznych w zakresie historii, nauczyciel - Szkoła Podstawowa w Piaskach. E-mail: lukaspuslecki@op.pl.

${ }^{1}$ Zob. np. Ł. Puślecki, O etapie literacko-naukowym w biografii Edmunda Bojanowskiego, „Scripta Comeniana Lesnensia. Miscellanea" 2010, nr 8, s. 109-119.
} 
Podstawą źródłową niniejszego artykułu będą dwa teksty E. Bojanowskiego ${ }^{2}$. Ukazały się one w leszczyńskim czasopiśmie „Przyjaciel Ludu”, wydawanym w latach 1834-1849, prezentującym wysoki poziom, ukazującym się w ogromnym - jak na ówczesne standardy - nakładzie, ilustrowanym, popularnonaukowym „tygodniku potrzebnych i pożytecznych wiadomości”.

Ostatnio ukazała się edycja źródłowa prac, notatek, najogólniej wszelkich niepublikowanych dotąd tekstów E. Bojanowskiego przechowywanych w archiwum sióstr służebniczek w Dębicy ${ }^{4}$. Dostępne stało się odtąd pełne spektrum dorobku Bojanowskiego, które niewątpliwie przyczyni się do podejmowania nowych badań. Źródła te nie zostaną jednak wykorzystane w niniejszym artykule z kilku względów. Przede wszystkim ich uwzględnienie uniemożliwiają jego ograniczone ramy objętościowe. Jest to bowiem materiał na osobne, obszerne opracowanie. Należy to potraktować jako postulat badawczy na przyszłość. Ponadto materiały te jako nieopublikowane nie odegrały, niestety, żadnej roli w zakresie badań regionalnych, stanowią jednakże świadectwo trwałej pasji i zainteresowań historyczno-regionalnych Bojanowskiego. Zostaną one tu przywołane w kontekście opisanej przez niego w „Przyjacielu Ludu” legendy na temat gostyńskiej piety. Warto też podkreślić, że teksty Bojanowskiego na temat historii regionu i ludoznawstwa nie były tylko przejawem osobistych pasji, ale - wpisując się w jego aktywność społeczną - stanowiły element szerzej zakrojonej akcji. W ramach Wydziału Literackiego Kasyna Gostyńskiego stworzył on bowiem grupę badaczy folkloru i tradycji historycznych subregionu gostyńskiego, która ściśle współpracowała z leszczyńskim „Przyjacielem Ludu”, będącym publikatorem zebranych materiałów regionalnych ${ }^{5}$.

${ }^{2}$ E.B. [E. Bojanowski], Kasper Miaskowski, „Przyjaciel Ludu” R. 4, 1837, nr 14, s. 111-112; [E. Bojanowski], Do malowniczej podróży po Wielko-Polsce, Gostyń i jego okolica, „Przyjaciel Ludu” R. 5, 1839, nr 27, s. 210-212; nr 28, s. 222-224.

${ }^{3}$ Zob. np. W. Jakóbczyk, Prasa polska w Wielkopolsce w latach 1832-1858, w: Prasa polska w latach 1661-1864, red. J. Łojek, t. 1, Warszawa 1976, s. 249; S. Karwowski, Czasopisma wielkopolskie, cz. I: 1796-1859, Poznań 1908, s. 38-39; E. Pieścikowski, „Ach! W tym Poznańskiem...”. Życie literackie XIX wieku, Poznań 2003, s. 47-50; A. Żalik, Współpraca Edmunda Bojanowskiego z „Przyjacielem Ludu”, w: Sługa Boży Edmund Bojanowski i jego troska o człowieka. Materiały z II sympozjum, Grabonóg 1991, s. 58-66.

${ }^{4}$ Prace, szkice i notatki Edmunda Bojanowskiego. Inedita, red. E. Gigilewicz, M.L. Opiela, t. I-II, Lublin 2016.

${ }^{5}$ Swój program badań regionalnych i przekształcenia Wydziału Literackiego Kasyna Gostyńskiego w ośrodek takich badań zaprezentował Bojanowski w 1842 r. - E.B. [E. Bojanowski], Rzecz o dylettantyzmie literackim, czytana na posiedzeniu literackiem w Gostyniu dnia 7 maja 1842, „Przyjaciel Ludu” R. 9, 1842, nr 2, s. 12-14; nr 3, s. 23-24; nr 5, s. 38-39. Por. Ł. Puślecki, Fascynacja i edukacja. Program badań folklorystycznych Edmunda Bojanowskiego jako system wymiany intelektualnej, w: Dziedzictwo myśli pedagogicznej Edmunda Bojanowskiego we współczesnej edukacji w Polsce i na świecie, red. M.L. Opiela, Lublin 2014, s. 133-155; tenże, Wielkopolskie programy badań folklorystycznych w pierwszej połowie XIX wieku, „Studia Zachodnie” 2015, t. 17, s. 106-113; 


\section{Epitafium zapomnianego poety}

W momencie, gdy E. Bojanowski opublikował w „Przyjacielu Ludu” artykuł, poświęcony pochodzącemu z ziemi gostyńskiej poecie z przełomu XVI i XVII w., miał już za sobą kilkuletnią współpracę z leszczyńskim periodykiem. Jego pierwsze teksty, pisane w czasach wrocławskich studiów, miały charakter krajoznawczych opisów zabytków Śląska oraz popularyzatorskich biografii postaci z epoki średniowiecza związanych z historią tego regionu' ${ }^{6}$. Już w tych artykułach znajdujemy świadectwa historycznych i krajoznawczych pasji i zainteresowań ich autora. Geneza pierwszego tekstu Bojanowskiego, dotyczącego subregionu gostyńskiego, związana jest z jego wyraźnie dostrzegalnym i głębokim zainteresowaniem zabytkami, architekturą, budownictwem (głównie sakralnym i ludowym $)^{7}$. Prawdopodobnie w czasie letnich wakacji jego uwagę zwróciła płyta epitafijna, znajdująca się w ścianie kościoła w Strzelcach Wielkich koło Gostynia. Od najmłodszych lat Bojanowski widział ją zapewne nieraz, gdyż kościół w tej miejscowości był jego świątynią parafialną. Jako student, w którym oprócz ambicji literackich rozwijały się równolegle pasje historyczne, postanowił zgłębić biografię osoby, której upamiętnieniu poświęcony był ów obiekt. W efekcie dokonał odkrycia o niebagatelnym znaczeniu dla historii regionu i polskich badań historyczno-literackich. Okazało się, że płyta-nagrobek, „który przeszło lat dwieście niezwrócił oczu niczyich”, należał do pochodzącego z pobliskiego Smogorzewa Kaspra Miaskowskiego, który „był znakomitym poetą i niejednego z współczesnych prześcignął w gładkości, dowcipie i wdzięku"s.

Przy okazji tego przypadkowego odkrycia poczynił Bojanowski pewne spostrzeżenia, odnoszące się do materialnych źródeł historycznych. W duchu romantycznego historyzmu, wedle którego należało poznać swój kraj, zinwentaryzować różnego rodzaju zabytki, stwierdził on, że „wiele pomników po kościołach naszych leży w zaniechaniu, z którychby może niejeden do dawnych dziejów

D. Strumiłło, Z dziejów zbieractwa wielkopolskiego XIX w. Kasyno w Gostyniu - Przyjaciel Ludu Związek Zbieraczy Starożytności Krajowych w Szamotułach, „Muzealnictwo” 1958, nr 7/8, s. 5-12.

${ }^{6}$ Większość tych ilustrowanych poglądowymi rycinami tekstów została opublikowana anonimowo. Jednak analiza ich treści, wzajemne odwołania między tekstami tego samego anonimowego autora wraz z korespondencją E. Bojanowskiego z redaktorem leszczyńskiego pisma pozwalają przypisywać mu autorstwo swoistej serii artykułów krajoznawczych ze Śląska oraz kilku tekstów o innej tematyce. Chodzi tu o 9 artykułów z „Przyjaciela Ludu” z lat 1834-1837 - S. Chociej, Twórczość literacka i działalność wydawnicza Edmunda Bojanowskiego, „Nasza Przeszłość” 1967, t. XXVI, s. 170-174; S. Jankowiak, Edmund Bojanowski 1814-1871. Życie i działalność. Bibliografia, Grabonóg 1995, s. 28.

7 Świadectwem owych zainteresowań jest wiele fragmentów jego Dziennika oraz wspomnianych wyżej, wydanych ostatnio luźnych notatek.

${ }^{8}$ E.B. [E. Bojanowski], Kasper Miaskowski, „Przyjaciel Ludu” R. 4, 1837, nr 14, s. 111. 
ciekawą przydał wiadomość, i w rozpadłych ruinach domowej zeszłości, nie jedną szczerbkę zapełnił"’. W tych i dalszych słowach wyraźnie widać - oględną wszelako i delikatną - uwagę autora pod adresem księży proboszczów, którzy nie zawsze należycie troszczyli się o zabytki znajdujące się w powierzonych ich pieczy świątyniach. Zdaniem Bojanowskiego „księża więc nasi powinni pilnie baczyć na to, i takich ważnych zabytków po zasłużonych przodkach udzielać całemu narodowi, jako wspólnej puścizny, a «Przyjaciel Ludu», chętnie je będzie obnosił po domach wszystkiej rozległej rodziny" ${ }^{10}$. Postulat ten świadczy o tym, że autor starał się propagować - szczególnie wśród kleru - inicjatywę ratowania, inwentaryzacji i opisywania zabytków, co mieściłoby się idealnie w nurcie wielkopolskiego regionalizmu historycznego i współczesnego, tak charakterystycznego dla publicystyki „Przyjaciela Ludu”11.

E. Bojanowski - zgodnie z założeniami redakcyjnymi leszczyńskiego pisma zamieszczał przy swoich tekstach ilustracje, ryciny - pełniące poglądową funkcję i odgrywające zapewne niepoślednią rolę w zainteresowaniu czytelników lekturą ${ }^{12}$. Także do omawianego tu artykułu dołączona została rycina przedstawiająca epitafium Kaspra Miaskowskiego. Rysunek ten sporządził prawdopodobnie sam Bojanowski. Odkryty i spopularyzowany przez niego zabytek zachował się do dziś w praktycznie niezmienionym stanie (brakuje tylko krzyża, który na rycinie Bojanowskiego znajdował się nad epitafium).

Artykuł Bojanowskiego jest opracowaniem głównie historycznym, z zakresu historii regionalnej, choć również historyczno-literackim. W tym ostatnim aspekcie jego znaczenie polega na prekursorstwie. Zwięzłe omówienie dorobku literackiego Miaskowskiego odegrało bowiem inspirującą rolę w inicjowaniu

9 Tamże.

10 Tamże.

11 Ten aspekt programu leszczyńskiego pisma mocno eksponował Edward Pieścikowski („Ach! W tym Poznańskiem...”..., s. 47-50)

12 O tym, jak bardzo redakcji zależało na ilustrowanych artykułach, pisał w listach do E. Bojanowskiego redaktor „Przyjaciela Ludu” - Listy Jana Poplińskiego do E. Bojanowskiego z 7.02.1835 i 15.02.1835, w: Korespondencja Edmunda Bojanowskiego z lat 1829-1871, t. 2: Listy do Edmunda Bojanowskiego z lat 1829-1868, objaśnił, skomentował i zarysem monograficznym poprzedził L. Smołka, Wrocław 2001, s. 42-43. Fragment listu J. Poplińskiego do E. Bojanowskiego Alina Hinc cytuje jako exemplum zabiegów redaktora, aby pozyskiwać jak najwięcej artykułów zaopatrzonych w ryciny - A. Hinc, Obraz dziejów ojczystych w pozaszkolnej edukacji historycznej społeczeństwa polskiego w Wielkim Księstwie Poznańskim w pierwszej połowie XIX wieku, Poznań 2007, s. 73-74. Założeniem takiej polityki redakcyjnej było przyciągnięcie - za pomocą materiału ilustracyjnego - uwagi czytelnika, skutkiem natomiast ogromna ilość materiału ikonograficznego na łamach „Przyjaciela Ludu”, w efekcie czego był on jednym z najbardziej atrakcyjnych ówczesnych polskich pism ilustrowanych. Kazimierz Jarochowski w 1884 r. wyraził opinię, iż wątpi, aby istniało jakiekolwiek inne polskie czasopismo, które mogłoby się równać pod tym względem z „Przyjacielem Ludu” - K. Jarochowski, Literatura poznańska w pierwszej połowie bieżacego stulecia, Poznań 1884, s. 62. 
badań nad twórczością tego poety ${ }^{13}$. Obecnie Miaskowski uchodzi za jednego z najwybitniejszych twórców nie tylko epoki baroku, ale i pogranicza renesansu i baroku. Nie miejsce tu na prezentowanie jego twórczości, można odesłać czytelnika do historyczno-literackiej syntezy Czesława Hernasa lub najbardziej wyczerpującego opracowania Stefana Nieznanowskiego ${ }^{14}$. Wartość krótkiego artykułu Bojanowskiego poświadczają konstatacje badaczy piszących o Miaskowskim, którzy zwracają uwagę na okoliczność, iż poeta ten był niezwykle popularny wśród sobie współczesnych, a potem całkowicie niemal zapomniany i w XIX wieku na nowo odkryty ${ }^{15}$. O tym, jak bardzo nieznaną i zapomnianą postacią był Miaskowski, świadczy to, że głównym, nieomal jedynym źródłem danych biograficznych na jego temat była dla Bojanowskiego wspomniana tablica epitafijna. Poza jej graficznym wyobrażeniem zacytował też w artykule jej treść, której autorem był sam Miaskowski ${ }^{16}$. Informacje biograficzne (głównie daty) z epitafium Bojanowski uzupełnił poszukiwaniami w herbarzach, księgach kościelnych oraz pracach z zakresu historii literatury. Odnośnie dorobku poetyckiego mimo usilnych poszukiwań znalazł on ledwie trzy wzmianki na temat Kaspra Miaskowskiego w pracach dotyczących dziejów

13 Przedstawiając twórczość Miaskowskiego, Bojanowski scharakteryzował krótko zawartość dwóch wydań Zbioru rythmów - z 1612 i 1622 roku. Wspomniał również o dwukrotnie opublikowanym za życia autora Herkulesie słowieńskim. Omówienie twórczości Miaskowskiego inkrustowane jest kilkoma cytatami z jego poezji. Najbardziej obszerny pochodzi z Walety Włoszczonowskiej, uchodzącej za jeden $z$ bardziej udanych wierszy poety.

${ }^{14}$ C. Hernas, Barok, Warszawa 1973, s. 77-86; S. Nieznanowski, O poezji Kaspra Miaskowskiego. Studium o ksztattowaniu się baroku w poezji polskiej, Lublin 1965. W twórczości Kaspra Miaskowskiego wyróżnić można kilka sfer tematycznych: poezja religijna, poezja ziemiańsko-wiejska, poezja polityczna. Za jego największe osiągnięcie artystyczne uchodzą wiersze nawiązujące do tematyki Bożego Narodzenia. Utworom Miaskowskiego o treści religijnej można przypisać charakter apologetyczny - zwalczający herezję protestancką w duchu nauczania Soboru Trydenckiego. W poezji politycznej piętnował błędy rozpasanej wolności szlacheckiej, ale jednocześnie obawiał się absolutum dominium.

15 Zob. np. A. Niewolak-Krzywda, Poeta wewnętrznych niepokojów - Kasper Miaskowski, w: Pisarze staropolscy. Sylwetki, red. S. Grzeszczuk, t. 2, Warszawa 1997, s. 507 i n.

${ }^{16}$ E.B. [E. Bojanowski], Kasper Miaskowski..., s. 111: „D.O.M. [Deo Optimo Maximo - z łac. „Bogu Najlepszemu Największemu” - Ł.P.] | Kasper Miaskowski, co miał śmiertelnego | W tym zawarł grobie, aż do dnia onego | Gdy głuche ciała trąba głosić będzie | A ogniem z nieba spłonie ziemia wszędzie. | Ale co dowcip dał mu był nie podły | Słowiańskiem bluszczem muzy to obwiodły. | Zasnął w Panu Bogu dnia XXII. | Kwietnia Roku Pańskiego | MDCXXII. wieku swego | LXXIII. który wszy | stek w pobożności | chrześciańskiéj, | Na czytaniu | i Pisaniu uczo | nych Pism | przeżył”. Cytat Bojanowskiego początkowo zachował wiernie układ wersów epitafium (tu zasygnalizowany znakiem |). Od fragmentu „zasnął w Panu...” już go nie respektował. Także pisownia została w wielu przypadkach przez Bojanowskiego uwspółcześniona. Autor popełnił też jeden błąd - w cytacie zamiast słowa „budzić” pojawiło się "głosić” we fragmencie „gdy głuche ciała trąba...”. Cały napis ponadto oddany jest wielkimi literami w oryginale, w przedruku natomiast wielkie litery pojawiają się na początku wyrazów rozpoczynających nowy wiersz oraz przy niektórych wyrażeniach typu „Panu Bogu”, „Roku Pańskiego”. 
poezji i powołał się na nie w ramach przypisu ${ }^{17}$. W Nowym Korbucie, w haśle literackim K. Miaskowskiego, wymieniono, poza nimi, tylko dwie inne prace, w których przed artykułem Bojanowskiego wzmiankowany był Miaskowski ${ }^{18}$. Charakterystyczna to okoliczność, świadcząca z jednej strony o tym, jak bardzo zapomnianym twórcą był wówczas Miaskowski, z drugiej zaś strony o tym, jak gruntowną kwerendę biblioteczną przeprowadził Bojanowski, przygotowując swe opracowanie.

Artykuł E. Bojanowskiego o K. Miaskowskim odbił się szerokim echem, zyskując status historycznego odkrycia. Jego recepcja - jak na XIX-wieczne realia - była błyskawiczna. Zakres oddziaływania tekstu Bojanowskiego zwiększył niewątpliwie fakt jego przedrukowania w warszawskiej „Gazecie Codziennej” w lutym 1838 roku $^{19}$. Artykuł ten zainspirował do dalszych badań w pierwszym rzędzie dwóch uczonych - warszawskiego prawnika, historyka, slawistę Wacława Aleksandra Maciejowskiego i poznańskiego profesora gimnazjalnego, historyka literatury Jana Rymarkiewicza ${ }^{20}$. Maciejowski w 1840 r. opublikował w poznańskim „Tygodniku Literackim” swój artykuł na temat Miaskowskiego ${ }^{21}$. W przypisie warszawski historyk przywołał opracowanie autorstwa Bojanowskiego z „Gazety Codziennej”22. Było ono dla niego podstawowym źródłem informacji biograficznych o Miaskowskim.

Zakrojone na większą skalę badania dotyczące twórczości Miaskowskiego prowadził J. Rymarkiewicz. Badacz ten przygotował reedycję zbioru poezji Miaskowskiego, która niewątpliwie znacząco wpłynęła na późniejszą szerszą recepcję twórczości barokowego poety ${ }^{23}$. Rymarkiewicz nie próbował przypi-

17 Tamże.

${ }_{18}$ Bibliografia Literatury Polskiej - Nowy Korbut, t. 2: Piśmiennictwo Staropolskie. Hasła osobowe: A-M, Warszawa 1964, s. 515-516.

${ }^{19}$ E.B. [E. Bojanowski], Kasper Miaskowski, „Gazeta Codzienna” 1838, nr 2040, s. 3-4. Tekst ten w porównaniu $\mathrm{z}$ pierwotną wersją jest nieznacznie skrócony. Usunięte zostały niewielkie fragmenty, głównie zawierające odwołania do wielkopolskich odbiorców, czytelników „Przyjaciela Ludu”. Brak w nim też ryciny przedstawiającej płytę epitafijną K. Miaskowskiego. Przedruk tekstu Bojanowskiego w warszawskim czasopiśmie nie jest przywoływany w literaturze przedmiotu ani w zestawieniu bibliograficznym S. Jankowiaka (Edmund Bojanowski 1814-1871...).

${ }_{20}$ Zob. np. J. Bardach, Wacław Aleksander Maciejowski i jego współcześni, Wrocław-Warszawa 1971; L. Słowiński, Rymarkiewicz Jan (1811-1889), w: Wielkopolski słownik biograficzny, Warszawa-Poznań 1981, s. 639.

${ }^{21}$ W.A. Maciejowski, Wspomnienia pisarzów dawnych. Kasper Miaskowski, „Tygodnik Literacki” 1840, nr 44, s. 347-349.

${ }^{22}$ Tamże, s. 347. Twórczość Miaskowskiego szeroko omówił później Maciejowski także w swoim opracowaniu Piśmiennictwo polskie od czasów najdawniejszych aż do roku 1830, t. 1, Warszawa 1851, s. 721-737; t. 2, Warszawa 1852, s. 983.

${ }^{23}$ Zbiór rythmów Kaspra Miaskowskiego znowu przez autora poprawionych, rozszerzonych i na dwie części podzielonych, w Poznaniu w drukarni J. Rossowskiego roku 1622, teraz do druku po raz trzeci podany, przejrzany, objaśniony i wiadomościq o życiu i pismach Miaskowskiego opatrzony przezJ. Rymarkiewicza..., t. 1-2, Poznań 1855. To poetyckie opus vitae Miaskowskiego zostało ponownie wydane w całości w 1995 roku 
sać sobie zasługi odkrycia postaci i twórczości K. Miaskowskiego. Uczciwie wskazał na prekursora w tej dziedzinie, określając go dodatkowo pochlebnym sformułowaniem: „Cała bowiem wiedza w tym względzie ogranicza się na kombinacjach opartych na napisie grobowym, po dwu niemal wiekach zapomnienia odkrytym przez czcigodnego pana Edmunda Bojanowskiego, w kościele parafialnym w Wielkim Strzelczu"24. Mimo tego, w świadomości wielu autorów to właśnie Rymarkiewicz utrwalił się - wbrew jego własnej deklaracji przypisującej pierwszeństwo Bojanowskiemu - jako ten, który „odgrzebał z wiekowego pyłu drogocenne po Miaskowskim zabytki”25. Rymarkiewicz, w początkach swych badań nad życiem i twórczością Miaskowskiego, traktował E. Bojanowskiego jako eksperta w tej dziedzinie. W 1855 r. zwrócił się do niego z prośbą o wskazówki i użyczenie notatek poczynionych przy okazji przygotowywania artykułu dla „Przyjaciela Ludu”26. To samo uczynił Stanisław Egbert Koźmian w 1856 r. Prosił on wówczas E. Bojanowskiego o materiały i wiadomości na temat dworku Miaskowskiego w Smogorzewie ${ }^{27}$. Bojanowski był szczęśliwy, że poetą z ziemi gostyńskiej, którego wydobył z zapomnienia, zaczynają interesować się badacze, a jego twórczość, dzięki reedycji Zbioru rythmów trafi na półki księgarskie. Pisał on bowiem: „Zobaczyłem się potem niespodziewanie z Janem Rymarkiewiczem, profesorem, który do Godurowa na kilka dni zjechał, aby śledzić szczegóły tyczące się Kaspra Miaskowskiego, którego pomnik w kościele strzeleckim w r. 1837 odkryłem, a teraz jego dzieła w Poznaniu przedrukowywane być mają [...] Miło mi, że moje przypadkowe odkrycie zwróciło uwagę na tego męża, który dawno zasługiwal, aby lepiej niż dotąd pamiętano o nim"28.

w ramach serii „Biblioteka pisarzy staropolskich” - K. Miaskowski, Zbiór rytmów, wyd. A. NowickaJeżowa, Warszawa 1995.

${ }^{24}$ J. Rymarkiewicz, Wiadomość o życiu i pismach Kaspra Miaskowskiego, w: Zbiór rythmów Kaspra Miaskowskiego..., s. VII.

${ }_{25}$ T.Ż. [Teodor Żychliński - przyp. moje - Ł.P.], Smogorzewo i Strzelcze. (Przyczynek do życiorysu Kaspra Miaskowskiego), „Tygodnik Ilustrowany”(Warszawa) 1864, t. X, nr 256, s. 308.

${ }^{26}$ E. Bojanowski, Dziennik, wydanie kompletne rękopisu i luźnych kartek Dziennika wraz z zapisami dziennymi Ochronka Podrzecza 1851-1854 i relacją s. Elżbiety Szkudłapskiej Ostatnie dnie życia i pogrzeb, objaśnił, skomentował i wstępem poprzedził L. Smołka, t. I, Wrocław 2009, s. 710.

27 Tamże, t. II, s. 48-49. Kwestia dworku Kaspra Miaskowskiego w Smogorzewie była wówczas aktualna, gdyż 16 marca 1856 r. na skutek pożaru uległ on zniszczeniu (tamże, s. 42). Stanisław E. Koźmian był powstańcem listopadowym, emigrantem politycznym, literatem, ziemianinem osiadłym w Przylepkach k. Śremu, bratem znanego ks. Jana Koźmiana, współredaktorem ultramontańskiego „Przeglądu Poznańskiego”, bardzo ściśle współpracował z E. Bojanowskim na niwie wydawniczej oraz ochronkowej - zob. np. B. Wysocka, Koźmian Stanisław Egbert (1811-1885), w: Wielkopolski słownik biograficzny..., s. 374-375; P. Matusik, Religia i naród. Życie i myśl Jana Koźmiana 1814-1877, Poznań 1998.

${ }_{28}$ E. Bojanowski, Dziennik..., t. I, s. 687-688. Wymienione w tekście Godurowo koło Gostynia, w którym przebywał Rymarkiewicz w czasie prowadzenia swoich badań, było majątkiem należącym do Franciszka Żółtowskiego, jednego ze znaczniejszych miejscowych ziemian - Majątki Wielkopolskie, t. I: Powiat Gostyński, red. J. Skuratowicz, Szreniawa 1997, s. 67. 
E. Bojanowski próbował wykorzystać Kaspra Miaskowskiego do budowania świadomości lokalnej, historyczno-kulturalnej miejscowego społeczeństwa. Z zaprzyjaźnionymi księżmi ze Strzelec Wielkich - Stanisławem Gieburowskim i Janem Grześkiewiczem - planowali w 1856 r. zorganizować żałobne obchody ku czci Adama Mickiewicza przy grobie K. Miaskowskiego. Były też plany utworzenia w Strzelcach Wielkich ochronki wiejskiej i szpitala, które otrzymałyby imię Kaspra Miaskowskiego ${ }^{29}$. W późniejszych czasach regionaliści i publicyści opisywali, przypominali lokalnej społeczności słynnego poetę z ziemi gostyńskiej $^{30}$. Pamięć o nim propagowana jest obecnie dość intensywnie w gminie Piaski, w której położone jest Smogorzewo - rodzinna miejscowość twórcy.

Ciekawą sprawą jest też duże zainteresowanie, jakie wobec twórczości K. Miaskowskiego okazywał Henryk Sienkiewicz. Słynny prozaik niezwykle pochlebnie wypowiadał się o jakości pióra Miaskowskiego, któremu poświęcił większe opracowanie $^{31}$. Można przypuszczać, że autor ten, chcąc wczuć się w specyfikę XVII w., język, sposób myślenia i postrzegania świata ówczesnej szlachty, postanowił gruntownie zapoznać się z jego twórczością.

Artykułem o Kasprze Miaskowskim, inspirującym dalsze badania biografii i twórczości poety, zapewnił sobie Bojanowski miejsce w dziejach polskich badań historyczno-literackich nad literaturą baroku oraz historycznych badań regionalnych.

\section{Malownicza „podróż swojaka po swojszczyźnie”}

W XIX w. zrodził się żywy ruch zainteresowania narodową przeszłością. Nie tylko w wymiarze ogólnonarodowych dziejów, ale także regionalnych. Występujące wówczas dążenie badaczy do inwentaryzacji pamiątek przeszłości i poznania kultury mieszkańców ziem polskich miało uzasadnienie w romantycznym historyzmie $^{32}$. Ta antykwaryczna tendencja zauważalna była na ziemiach polskich

29 E. Bojanowski, Dziennik..., t. II, s. 19.

30 Zob. np. Z. Miszewska, Piewca złej i dobrej doli Rzeczypospolitej (Kasper Miaskowski), „Kronika Gostyńska” 1931, nr 1, s. 1-10; L. Męczarski, Pamięci Kaspra Miaskowskiego barokowego poety ziemi gostyńskiej w 450 rocznicę urodzin, „Gazeta Gostyńska” 1999, nr 21, s. 42; nr 22, s. 39; A. Siama, Szlacheckie zaślubiny. Szkic o epitalamium Kaspra Miaskowskiego, „Grabonoskie Zapiski Regionalne” 2006, t. 12, s. 43-49; S. Sroka, Kasper Miaskowski - poeta nieznany, „Przyjaciel Ludu” [nowy] 1986, nr 1, s. 22-24; A. Żalik, Poeta Kasper Miaskowski ze Smogorzewa, Piaski 1988.

31 Ukazywało się ono w odcinkach w „Tygodniku Ilustrowanym” z 1870 r. (numery 127-129). Jako jednolity tekst zostało wydane w 1904 r.: H. Sienkiewicz, Kasper Miaskowski (Studyum literackie), w: Pisma Henryka Sienkiewicza nieobjęte wydaniem zbiorowem, cz. 1: Pisma młodociane. Mikołaj Sęp Szarzyński. Kasper Miaskowski, Warszawa 1904, s. 41-100.

${ }^{32} \mathrm{~W}$ romantycznym historyzmie, traktując naród jako jedność pokoleń zmarłych, żyjących aktualnie i mających się w przyszłości narodzić, przypisywano temu bytowi historycznie 
od utraty niepodległości, nasiliła się po kongresie wiedeńskim, a jej apogeum przypadło na czasy międzypowstaniowe. Fascynacja krajoznawstwem i regionalizmem była w pewnym sensie ucieczką w przeszłość w obliczu trudnej rzeczywistości niewoli politycznej. Miała ona ponadto na celu pielęgnowanie tego wszystkiego, co mogło być budulcem polskiej świadomości narodowej. Istotnym motywem zainteresowań regionalnych, integrujących poczucie więzi lokalnej i ogólnonarodowej, było też „dążenie do legitymizacji polskości najbliższych badaczowi obszarów (również w emocjonalnym znaczeniu) znajdujących się pod obcym panowaniem" ${ }^{33}$. Bardzo popularne były wówczas opisy podróży. Wśród prekursorów i najgłośniejszych autorów tego rodzaju dzieł wymienia się m.in.: Klementynę z Tańskich Hoffmanową, Józefa Ignacego Kraszewskiego, Aleksandra Przeździeckiego, Seweryna Goszczyńskiego, Edwarda Raczyńskiego, Kazimierza Kontryma, Adama Ludwika Jucewicza i Władysława Syrokomlę (Ludwika Kondratowicza) ${ }^{34}$. Co prawda, początkowo dominowało, w dużej mierze za sprawą twórczości wielkich poetów romantycznych, zainteresowanie kresami wschodnimi.

Kultura polska w XIX wieku, wskutek wydarzeń politycznych, traciła jednak coraz bardziej tak wszechstronne we wcześniejszych wiekach związki ze Wschodem. Utwierdzała się wówczas coraz silniej więź z kulturą zachodniej Europy. Ta reorientacja pociągała za sobą stopniowe przesunięcie zainteresowań, także krajoznawczych i regionalistycznych, w kierunku Wielkopolski oraz polskich ziem zachodnich i północnych ${ }^{35}$. Słynny piewca Litwy Władysław Syrokomla, odwiedziwszy w $1858 \mathrm{r}$. Wielkopolskę, napisał poświęcony swej peregrynacji szkic. Opatrzył go tytułem Podróż swojaka po swojszczyźnie, który w literaturze przedmiotu stał się hasłem charakteryzującym rodzime podróżopisarstwo XIX-wieczne, w związku z czym piszący te słowa pozwolił sobie użyć go w tytule rozdziału ${ }^{36}$. Okazuje się, że dla Syrokomli swojskość nie była tożsama li tylko

ukształtowaną indywidualność. Wszelka refleksja nad teraźniejszością i przyszłością musiała więc odwoływać się przede wszystkim do przeszłości - M. Janion, M. Żmigrodzka, Romantyzm i historia, Gdańsk 2001, s. 7-10.

${ }_{33}$ A. Wierzbicki, Historiografia polska doby romantyzmu, Wrocław 1999, s. 242-243.

${ }^{34}$ Autorzy ci poznanie własnego kraju traktowali w kategoriach patriotycznego obowiązku. W tym kontekście podróże zagraniczne i ich entuzjastyczne opisy poczytywano w epoce porozbiorowej za rzecz niestosowną, wynikającą ze snobizmu, kosmopolityzmu, pogardy do wszystkiego co rodzime - zob. np. K. Hoffmanowa, Opis różnych okolic Królestwa Polskiego, t. 1: Z widokiem Puław, Wrocław 1833 , s. 2. W. Syrokomla w jednej ze swoich pierwszych relacji zapisał słowa symptomatyczne dla całego ruchu podróżopisarstwa romantycznego: „Wolno nie być głębokim badaczem; ale pod karą haniebnego wstydu nie godzi się nie znać zupełnie ziemi, na której mieszkamy, albo - co gorsza - znać lepiej kraje obce niż własny" - W. Syrokomla, Wycieczki po Litwie w promieniach od Wilna (Troki, Stokliszki, Jezno, Funie, Niemiez, Miedniki etc.), z rycina litografowana i drzeworytami, Wilno 1857, s. 7.

${ }^{35}$ S. Burkot, Polskie podróżopisarstwo romantyczne, Warszawa 1988, s. 232-233.

${ }^{36}$ Fragmenty relacji z podróży po Wielkopolsce ukazywały się w „Gazecie Codziennej” w 1858 r. Pełne wydanie nastąpiło wiele lat później: L. Kondratowicz (W. Syrokomla), Podróż swojaka po 
z okolicą najbliższą autorowi, z krajem lat dziecinnych. Zakres tego pojęcia obejmuje w jego refleksji wszystkie ziemie polskie. Przybysz z Litwy w Wielkopolsce czuł się u siebie. Rodzący się w XIX wieku regionalizm, ukazujący walory krajoznawcze poszczególnych regionów, zestawiający podobieństwa i różnorodność, nie był więc partykularnym ruchem społeczno-kulturowym poszczególnych regionów. Program inwentaryzacji śladów przeszłości, podbudowany poczuciem świadomości narodowej miał dowodzić polskości poszczególnych ziem dawnej Rzeczpospolitej.

W I połowie XIX w. w Wielkopolsce nie zrodził się żywszy ruch krajoznawczy. Mimo to wyróżnić należy w tym kontekście wezwanie Ryszarda Berwińskiego do odbywania „narodowych pielgrzymek”, działalność Edwarda Raczyńskiego, której ukoronowaniem były Wspomnienia Wielkopolski oraz publicystykę miejscowej prasy, głównie „Przyjaciela Ludu” ${ }^{37}$. W leszczyńskim periodyku pojawiła się imponująca ilość tekstów krajoznawczych ${ }^{38}$.

W nurt romantycznego krajoznawstwa wpisuje się artykuł Edmunda Bojanowskiego Do malowniczej podróży po Wielko-Polsce, Gostyń i jego okolica opublikowany w „Przyjacielu Ludu”. Świadectwem tego jest fakt, że autorka antologii romantycznego podróżopisarstwa umieściła jego fragment w swym zbiorze. Został on tam przedrukowany jako artykuł anonimowy, choć w świetle Dziennika Bojanowskiego wiadomo, że to on jest jego autorem ${ }^{39}$. Tekst podpisany został graficznym znakiem dwóch gwiazd. Stefan Jankowiak identyfikuje je jako jeden $z$ kryptonimów autorskich Bojanowskiego i nie ma żadnych wątpliwości, że to on jest autorem artykułu ${ }^{40}$. W treści znajdziemy wiele wskazówek świadczących pośrednio o jego autorstwie. „Przytoczyć jednak wystarczy rozstrzygający bez wątpliwości tę kwestię zapis z Dziennika Bojanowskiego, który w 1864 r., pożyczywszy od znajomego księdza pewną książkę przeznaczoną dla ludu, znalazł w niej moralizatorską powiastkę o Walentym z Grabonoga, rzeźbiarzu-chłopku. Po zapoznaniu się z jej treścią zanotował w Dzienniku, że jest ona „osnuta na wiadomości, którą o nim [Walentym - Ł.P.] kiedyś zamieściłem w opisie Gostynia w „Przyjacielu Ludu” ${ }^{\text {”11 }}$. Rzeczywiście lektura tego tekstu, będą-

swojszczyźnie, z rękopisu ogłosił W. Korotyński, Warszawa 1914. Por. M. Witkowski, Syrokomli wycieczka po swojszczyźnie, w: Literackie przystanki nad Wartą, red. Z. Szweykowski, Poznań 1962, s. 339-372.

${ }^{37}$ Ryszard B... [R. Berwiński], Listy z narodowej pielgrzymki..., „Przyjaciel Ludu” R. 5, 1838, nr 8, s. 60; nr 11, s. 82-83; nr 19, s. 148-150; nr 20, s. 154-156; E. Raczyński, Wspomnienia Wielkopolski to jest województw poznańskiego, kaliskiego i gnieźnieńskiego, t. 1-2, Poznań 1842-1843.

${ }^{38}$ Wykaz krajoznawczych artykułów wielkopolskiej prasy znajduje się w pracy: A. Hinc, Obraz dziejów ojczystych..., s. 71-77.

39 [Anonim], Gostyń i jego okolica, w: J. Kamionka-Straszakowa, „Do ziemi naszej”. Podróże romantyków, Kraków 1988, s. 243-247.

${ }^{40}$ S. Jankowiak, Edmund Bojanowski 1814-1871..., s. 26, 103.

${ }^{41}$ E. Bojanowski, Dziennik..., t. III, s. 466. 
cego opowieścią z wprowadzonymi partiami dialogowymi, wykazuje wyraźną zależność w stosunku do narracji Bojanowskiego. Wszystkie elementy życiorysu ludowego rzeźbiarza zostały w niej powtórzone za artykułem „Przyjaciela Ludu”. W kilku miejscach znajdują się dosłowne lub nieco zmodyfikowane cytaty ${ }^{42}$.

Tytuł artykułu Bojanowskiego zawierał deklarację, że opis gostyńskiej okolicy będzie miał charakter podróży „malowniczej”. Rzeczywiście aspekt ten został mocno wyeksponowany w narracji autora, jednak można w niej znaleźć także elementy innych odmian - historycznej, folklorystycznej, archeologicznej i przyrodniczej. Cechę „malowniczości” Bojanowski uzyskał, wprowadzając liczne informacje na temat kolorystyki prezentowanych obiektów przyrodniczych lub przestrzeni miejskiej ${ }^{43}$. Wiadomo skądinąd, że był on bardzo wrażliwy na piękno przyrody i potrafił z dużym talentem ją opisywać ${ }^{44}$. Jego tekst zawiera też elementy podróży przyrodniczej, ukazującej fachową charakterystykę podziwianych stron ${ }^{45}$.

W romantycznych relacjach $\mathrm{z}$ wędrówek po kraju przeplatały się ze sobą dwa sposoby narracji - pierwszy, odnoszący się do teraźniejszości, miał charakter reportażu, drugi, eksponujący przeszłość, zbliżał się do narracji historycznej ${ }^{46}$. Bojanowski dość harmonijnie łączy w swoim artykule te dwa elementy. Prezentacja współczesnego autorowi Gostynia jest ciekawą charakterystyką sytuacji

${ }^{42}$ b.a., Walenty rzeźbiarz, chłopek, w: Złota księga, w której zawarte sa przykłady cnót chrześcijańskich ludziom ku nauce i zabawie, Lwów 1861, s. 52-60. Na tej podstawie autorstwo Bojanowskiego stwierdziła już w latach 60. S. Chociej (Twórczość literacka..., s. 180-181).

${ }^{43}$ [E. Bojanowski], Do malowniczéj podróży po Wielko-Polsce, Gostyń i jego okolica, „Przyjaciel Ludu" R. 5, 1839, nr 27, s. 210-212; nr 28, s. 222-224.

${ }^{44} \mathrm{Na}$ ten temat można by napisać osobny artykuł. Dziennik Bojanowskiego pełen jest przykładów tej skłonności autora. Rejestrował on wszelkie ciekawe i piękne obiekty przyrody oraz zmiany wynikające z cykliczności pór roku. Notował informacje o datach pojawienia się na wiosnę słowików, bocianów, jaskółek, motyli, pszczół, żab, jaszczurek, fiołków itp. Niemal każdy zapis dzienny zaczynał od obserwacji pogody. Interesował się też przewidywaniem pogody, ludowymi przysłowiami na ten temat. Zamieścił też kilka sugestywnych opisów przyrody świadczących o typowo malarskim zmyśle estetycznym. Na temat malarstwa krajobrazowego toczył dysputy z ks. Bernardem Preibiszem - filipinem, malarzem, autorem fresków w świętogórskiej świątyni - E. Bojanowski, Dziennik..., t. I, s. 50, 62, 63, 64, 71, 74, 264-275, 501, 508, 686. Także w swojej młodzieńczej twórczości translatorskiej najlepsze efekty osiągnął, tłumacząc fragmenty będące opisami przyrody i uczuć. Opinię taką wyraziła autorka opracowania na temat pierwszych w naszej literaturze przekładów Byrona - R. Pakowska, Polskie przekłady poematów Byrona „Childe Harold” i „Manfred”, Kraków 1938, s. 49. Ponadto w swojej „ludomanii” za jedną z pozytywnych cech warstwy ludowej uważał zbliżenie jej życia do natury. Swój oryginalny system wychowania dziecka wiejskiego w ochronkach także w dużej mierze oparł na obcowaniu z przyrodą.

${ }^{45}$ Bojanowski zwrócił uwagę na kilka rzadkich okazów flory na podgostyńskich łąkach. Zostały one bardzo skrupulatnie i profesjonalnie zidentyfikowane i opisane (łącznie z nazwami łacińskimi i odesłaniem do prac znanego przyrodnika Stanisława Bonifacego Jundziłła). Autor stwierdził, że jego uwagę na wspomniane zioła zwrócił p. Rude, gostyński aptekarz - [E. Bojanowski], Do malowniczej podróży..., nr 28, s. 224.

${ }^{46}$ S. Burkot, Polskie podróżopisarstwo..., s. 280-281. 
społecznej i ekonomicznej prowincjonalnych miast tamtych czasów. Plastycznie ukazany został wygląd warsztatów i obejść rzemieślniczych, w których można obserwować pracę rękodzielniczą i jej efekty. Widoki takie mają, zdaniem Bojanowskiego, swój specyficzny urok. Jednak zarazem rzemieślnicze przedmieścia mogą być też świadectwem zacofania i stagnacji polskiego rzemiosła w mniejszych miastach: „Tu partacz nauczy się klecić skrzynki, lub szyć bóty [sic!], i mianuje się już majstrem, i osiwieje, niemyśląc o wędrówce, ani chcąc pamiętać, że gdzieindziej za lepszą robotę, lepszą dostają zapłatę i lepiej się mają" ${ }^{\text {" J }}$ Jeszcze gorzej - zdaniem autora - prezentowała się kondycja rodzimego kupiectwa, bardzo mocno zdominowanego przez Żydów, których niezbyt liczna populacja „trzyma przecież wszystek handel w ręku, jak w każdem naszem miasteczku"48. Przy charakterystyce społeczności żydowskiej Bojanowski jako bystry obserwator zwrócił uwagę na pewne zjawisko. Opisując wygląd żydowskich handlarzy, zauważył mianowicie, że miejscowi Żydzi od pewnego czasu porzucają swój tradycyjny strój, nosząc się „z francuska”, stają się podobni do niemieckich Żydów ${ }^{49}$. W tej krótkiej uwadze zasygnalizowany został proces częściowej asymilacji Żydów na ziemiach polskich pod pruskim panowaniem. Jeśli takowa asymilacja następowała, to prawie wyłącznie do kultury niemieckiej, a nie polskiej. Potwierdzeniem tych tendencji był rok 1848. Wobec konfliktu polsko-niemieckiego doby Wiosny Ludów elita społeczności żydowskiej stanęła wyraźnie po stronie Niemców ${ }^{50}$. Bojanowski nie wygłaszał jednak pretensji, zarzutów pod adresem Żydów w kontekście monopolizacji przez nich handlu. Podkreślał raczej pewną niechęć rodaków do zajmowania się kupiectwem. Nie omieszkał też wspomnieć, i - w omawianych okolicznościach - napiętnować, narodowej skłonności do pijaństwa: „krajowiec i tu się niepuszcza na zyski handlowe, tylko klepie biedę; a pod wiechą, w szynkowni, zastaniesz go w dnie święte ostatni grosz przepijającego, bo wódka tania i coraz więcej gorzalni się wznosi" ${ }^{1}$. Z opisu Bojanowskiego wyłania się obraz sennego, prowincjonalnego miasteczka. Przedmieścia są brudne i nieestetyczne, w rzemieślniczej części miasta dominują domostwa drewniane. Jedynie przy rynku były domy murowane, kryte dachówką, czasem piętrowe. Jednak i centrum miasta nie przedstawiało

47 [E. Bojanowski], Do malowniczej podróży..., nr 27, s. 210.

48 Tamże.

49 Tamże.

${ }^{50}$ Głównie zamożna część wielkopolskich Żydów, podzielająca poglądy ruchu oświecenia żydowskiego - haskali - dążyła do asymilacji z nacją niemiecką. Niemiecka, zmaterializowana, mieszczańsko-protestancka kultura była bowiem Żydom o wiele bliższa niż polska - idealistyczna, katolicko-rustykalna - Zob. np. S. Kieniewicz, Społeczeństwo polskie w powstaniu poznańskim 1848 roku, Warszawa 1960, s. 220; K. Makowski, Żydzi wobec Wiosny Ludów w Wielkim Księstwie Poznańskim, w: Żydzi w Wielkopolsce na przestrzeni dziejów, red. J. Topolski, K. Modelski, Poznań 1995, s. 149-167.

${ }^{51}$ [E. Bojanowski], Do malowniczej podróży..., nr 27, s. 210. 
się zbyt reprezentacyjnie: „błotny jednak środek rynku i skrzypiąca studnia, oznacza niewielką od przedmieść różnicę. I tutaj niewidać ni ruchu, ni życia; czasem tylko bryczka obywatelska przed sąd zaturkocze, a kilka razy w tydzień zatrąbi poczta, a kilka razy do roku rozstawiają się tasze jarmarczne [...] Po jarmarku pusto znowu w całem mieście" 52 .

W charakterystyce mieszkańców miasta często zwracał autor uwagę na ich ubóstwo, szczególnie na przedmieściu. W obrazowy sposób scharakteryzował obejście, które podróżny mógł zobaczyć, przejeżdżając drogą: „Na domowym progu leżą tylko ich nędzne dzieci [...] ich babkę z zaśniedziałym czepcem szychowym na siwej głowie, w wypłowiałej na chudych ramionach jupce, widać we drzwiach jak w ramach starego obrazu, albo krawędziach staro-świeckiej trumny" 33 .

Opis miasta wykorzystał Bojanowski do wygłoszenia kilku afirmatywnych zdań pochwały pod adresem działającego w Gostyniu od 1835 r. kasyna ${ }^{54}$. W jego słowach zdaje się pobrzmiewać dość powszechna wówczas opinia o pewnej stagnacji kulturalnej, braku aktywności, głównie intelektualnej, w społeczeństwie Wielkiego Księstwa Poznańskiego. Wychwalając działalność kasyna, pisze on bowiem tak: „Kto się wpatrzy w obumarłość, stężałość i płytkość naszego życia powszedniego, uzna łacno, jaką korzyść mogą nam przynieść takie towarzystwa, takie na wyższych drogach ścierania się zdań i wyobrażeń" ${ }^{55}$. Wielkie Księstwo Poznańskie na tle innych zaborów uchodziło za region mało aktywny na niwie kulturalnej, ospały pod względem życia intelektualnego. Różne oceny formułowane $\mathrm{w}$ tej kwestii przez twórców $\mathrm{z}$ innych regionów są jednak nieco krzywdzące i stereotypowe. W ich efekcie narodził się swoisty „kompleks braku kulturalnych tradycji i prowincjonalnego charakteru własnej kultury", określany czasem mianem wielkopolskiej czy kulturalnej Beocji ${ }^{56}$. Bojanowski podkreślał, że kasyno, ukierunkowane - co prawda - głównie na utylitarną działalność

${ }^{52}$ Tamże, s. 211.

53 Tamże, s. 210.

${ }_{54}$ Zob. np. S. Jankowiak, Kasyno Gostyńskie (1835-1846). U początków pracy organicznej w Wielkopolsce, Gostyń 1996.

${ }_{55}$ [E. Bojanowski], Do malowniczej podróży..., nr 27, s. 211. Przekonanie o stagnacji intelektualnej w Wielkopolsce czy na wielkopolskiej prowincji, znajdziemy także na kartach Dziennika Bojanowskiego, np. we fragmencie, w którym pisał on o „naszej bardzo nie czytającej okolicy” E. Bojanowski, Dziennik..., t. I, s. 217.

${ }^{56}$ B. Wysocka, Kultura literacka Wielkopolski w latach 1919-1939, Poznań 1990, s. 245. Miejscowym prekursorem złośliwych uwag na temat kultury wielkopolskiej w XIX wieku był najwybitniejszy tutejszy poeta tych czasów - Ryszard Berwiński, który w dygresyjnym poemacie Don Juan Poznański, we fragmencie zaczynającym się od słów „W Poznańskiem jednak, - ach! w tym Poznańskiem” ironicznie kpił z poziomu miejscowej literatury. Por. E. Pieścikowski, „Ach! W tym Poznańskiem...”..., s. 5-8; W. Molik, Etos Wielkopolan w historycznym rozwoju i ogladzie społecznym. Wprowadzenie do problematyki antologii, w: Etos Wielkopolan. Antologia tekstów o społeczeństwie Wielkopolski $z$ drugiej połowy XIX i XX wieku, wyb. i oprac. W. Molik, Poznań 2005, s. 30-34. 
w zakresie postępu w rolnictwie, stawia sobie też przecież cel zagospodarowania czasu wolnego okolicznego ziemiaństwa aktywnością intelektualną.

Na szczególną uwagę zasługiwała, jego zdaniem, bardzo zasobna biblioteka kasynowa, która dysponowała bogatym księgozbiorem, abonowała też prawie wszystkie ówczesne polskie czasopisma ${ }^{57}$. W późniejszym czasie stała się ona podstawą tworzenia biblioteki Poznańskiego Towarzystwa Przyjaciół Nauk $^{58}$. Warto w tym kontekście pamiętać, że w wielkopolskiej prasie pisano, iż działalność wydawnicza E. Bojanowskiego (almanach literacki „Pokłosie”) jest jednym $\mathrm{z}$ argumentów przeciwko omawianej tu tezie o kulturalnej stagnacji Wielkopolski ${ }^{59}$. W działalności kasyna podkreślił też Bojanowski aspekt dobroczynny, charytatywny - przeznaczanie dochodów z balów i loterii na pomoc potrzebującym ${ }^{60}$. Zachwalanie przez autora artykułu ideologii pracy organicznej, w wydaniu prezentowanym przez Kasyno Gostyńskie, jest pochwałą niezbędnych przemian cywilizacyjnych i aktywności polskiego społeczeństwa w ich obliczu. Modernizacja majątków ziemiańskich, aktywność obywatelska i intelektualna ziemian, działalność dobroczynna, propagowanie czytelnictwa i oświaty na wsi - wszystko utrzymane w duchu solidarnej współpracy całego społeczeństwa - były polecanym przez Bojanowskiego programem. Był on typowy dla rodzącej się w Wielkopolsce idei pracy organicznej.

Zdaje się, że w aspekcie opisu aktywności lokalnego ziemiaństwa skupionego w organicznikowskiej instytucji, zwanej kasynem, artykuł Bojanowskiego skłania się w kierunku jeszcze jednego z rodzajów romantycznego podróżopisarstwa. Wskutek przemian cywilizacyjnych XIX wieku, rodzącego się kapitalizmu, radykalnych ideologii społecznych i zachowawczej, organicznikowskiej idei postępu powstawały też relacje krajoznawcze scharakteryzowane jako „panoramiczna podróż cywilizacyjna"61. Romantyczna estetyka i historyzm zeszły w nich na dalszy plan kosztem ambicji propagowania przemian cywilizacyjnych i realistycznego ukazywania kierunku przekształceń życia społecznego. Tendencję tę widać także w innym fragmencie analizowanego tu artykułu. Odmalowując

57 [E. Bojanowski], Do malowniczej podróży..., nr 27, s. 211.

58 A. Kochlerówna, Biblioteka Poznańskiego Towarzystwa Przyjaciół Nauk 1857-1957, „Roczniki Historyczne” 1957, R. XXIII, s. 383, 388; A. Wojtkowski, Biblioteka Kasyna Gostyńskiego, „Kronika Gostyńska” 1933, nr 10, s. 159-164; B. Kosmanowa, Biblioteki polskie w Wielkim Księstwie Poznańskim, Poznań 1982, s. 79; Historia biblioteki, w: http://www.biblioteka.ptpn.poznan.pl/node/17 [dostęp: 14.08.2017].

59 b.a., Pokłosie, zbieranka literacka na korzyść sierot. Poznań, w komisie Ludwika Merzbacha, „Gazeta Wielkiego Księstwa Poznańskiego” 1855, nr 37, s. 3: „ten tomik możnaby śmiało wystawić przeciw dotkliwemu Kraszewskiego oskarżeniu, że Wielkopolska najniżej stoi ze wszystkich prowincyi polskich pod względem literatury, a osobliwie poezyi. Niech wydawca co rok takie zaprzeczenia daje, a zyska wdzięczność rodaków”.

${ }^{60}$ [E. Bojanowski], Do malowniczej podróży..., nr 27, s. 211.

${ }_{61}$ J. Kamionka-Straszakowa, „Do ziemi naszej”..., s. 73-77. 
słowem gostyńskie krajobrazy, Bojanowski z jednej strony na romantyczną modłę wprowadził pewne elementy tajemniczości i dramaturgii, pisząc o „łysej górze grabonoskiej”, która miała być siedliskiem czarownic i o „cmentarzu zarażonych w czasach morowego powietrza”, gdzie istniał onegdaj kościółek św. Rozalii ${ }^{62}$. Z drugiej jednak strony autor głosił pochwałę współczesnych przemian przestrzeni. Piękny, malowniczy, miły wydaje mu się krajobraz nie dzikiej przyrody, ale obszaru zaludniającego się dzięki powstającym nowym osadom uwłaszczonych chłopów: „uśmiechnęły mi się rzędem porozstawiane nowe osady, wyzwolonych chłopów, nasze polne «wolniki», niby do ukraińskich futorów podobne, które zaludniając samotne obszary, przydają tak świeży i miły wyraz do fizyonomyi naszych okolic. Dziś tam spokojne dymią lepianki, gdzie niegdyś chyba obozowe tliły się czasem ogniska"63.

Poza reportażową prezentacją współczesnej autorowi rzeczywistości znajdujemy w narracji Bojanowskiego sporo odniesień do historii. Wprowadzane są one mimochodem przy okazji omawiania poszczególnych miejsc i zabytków. Pojawiły się one m.in. w opisie bazyliki i klasztoru na Świętej Górze - najbardziej rozpoznawalnego gostyńskiego zabytku, nazywanego „najpiękniejszym gmachem [...] na całą okolicę między Poznaniem i Wrocławiem"64. Pisząc o początkach kultu Matki Boskiej czczonej w Gostyniu w wizerunkach madonny w głównym ołtarzu i piety w bocznym ołtarzu, Bojanowski odwołuje się do wydarzeń z czasów reformacyjnego zamętu religijnego z XVI w. Właścicielka Gostynia - Anna ze Zborowskich, „zagorzała kacerka”, nakazała zniszczyć otaczaną kultem przez gostyńskich katolików, słynącą łaskami i cudami figurę Matki Bożej Bolesnej (pietę) z kapliczki na Świętej Górze. Jednak heretycy nie mogli jej porąbać siekierami i młotami, ani spalić. Wrzucono ją więc do polnej studni i zasypano. Trzydzieści lat później miały miejsce cudowne zdarzenia - ze studni biło światło i ukazała się Bogurodzica, a lud katolicki wydobył figurę Najświętszej Panienki i umieścił ją w pobliskim drewnianym kościółku obok obrazu madonny malowanego na drewnie sprzed wieku XVI. Polne źródełko, do którego wrzucona została święta figura, otoczono później kapliczką. Znajduje się ona nieopodal obecnego klasztoru. Po chwilowych sukcesach reformacji Gostyń wrócił do katolicyzmu. Na miejscu drewnianego kościółka stoi dziś bazylika filipinów, a w niej wspomniana rzeźba i obraz w głównym ołtarzu. Autorstwo tego obrazu Bojanowski przypisuje ,jakiemuś proboszczowi wielko-strzeleckiemu”65.

Historię o początkach kultu Matki Boskiej na miejscu dzisiejszej bazyliki świętogórskiej zaczerpnął Bojanowski, jak informuje w przypisie, ze znajdującego

62 [E. Bojanowski], Do malowniczej podróży..., nr 28, s. 222, 223.

${ }_{63}$ Tamże, s. 222.

${ }^{64}$ M. Baliński, T. Lipiński, Starożytna Polska pod względem historycznym, jeograficznym i statystycznym, t. I, Warszawa 1885, s. 95.

${ }^{65}$ [E. Bojanowski], Do malowniczej podróży..., nr 28, s. 223. 
się w bibliotece klasztornej, opatrzonego datą 1671, opisu Adama Konarzewskiego, fundatora barokowej bazyliki filipinów ${ }^{66}$. Nie będziemy tu wchodzić w konfrontowanie narracji Bojanowskiego ze źródłami i literaturą dotyczącą bazyliki świętogórskiej. Jego relacja na temat gostyńskiej piety, jako oparta na archiwach filipińskich, jest $\mathrm{w}$ zasadzie tożsama $\mathrm{z}$ innymi źródłami, czy opisami w literaturze przedmiotu ${ }^{67}$. Wielkie przywiązanie E. Bojanowskiego do Świętej Góry jest powszechnie znane. Wynikało ono z wielu przesłanek (np. bliskość miejsca zamieszkania, piękno świątyni, pobożność maryjna Bojanowskiego, rodzinna tradycja o cudownym uzdrowieniu małego Edmunda za sprawą modłów Teresy Bojanowskiej do Matki Boskiej Gostyńskiej, czego świadectwem było jej wotum znajdujące się do dziś u stóp świętogórskiej piety $)^{68}$. Dziennik Bojanowskiego, zawierający szczegółowe wzmianki o praktykach religijnych, jest świadectwem tego, że bazylikę świętogórską traktował on jako swoją świątynię parafialną de facto, choć de iure był nią kościół w Strzelcach Wielkich, do którego uczęszczał on jednak sporadycznie, właściwie prawie wyłącznie na odpusty parafialne. Świadectwem emocjonalnych więzi łączących Bojanowskiego ze Świętą Górą oraz zainteresowania historią tego miejsca i kultu maryjnego jest opracowanie przez niego większego tekstu poświęconego gostyńskiej piecie. Zachował się on w jego archiwum i został upubliczniony w wydanym ostatnio dziele będącym edycją niepublikowanych dotychczas rękopisów ${ }^{69}$. Redakcja językowa tego tekstu świadczy o tym, że nie są to luźne zapiski, ale artykuł przygotowany do druku ${ }^{70}$.

${ }^{66}$ Te wpisy w kronice klasztornej sporządzone w języku łacińskim przez Konarzewskiego opierały się na przekazie ustnym. W dwudziestoleciu międzywojennym zachowało się z tego 11 uszkodzonych kartek. Resztę wyciął i zniszczył z pewnych względów założyciel miejscowej kongregacji filipinów i pierwszy jej zwierzchnik ks. Stanisław Grudowicz - S. Tabor, Krótki zarys historji cudownego obrazu Matki Boskiej Świętogórskiej, „Kronika Gostyńska” 1931, nr 2, s. 21.

${ }^{67}$ Jedna z ważniejszych kronik świętogórskich - spisana w latach 1827-1836 przez ks. Kaspra Dominikowskiego (Zbiór wiadomości o Świętej Górze pod Gostyniem...) - dostępna jest w zdygitalizowanej wersji w zasobach Wielkopolskiej Biblioteki Cyfrowej. W XIX w. ukazało się oparte na świętogórskich archiwaliach dwutomowe wydawnictwo jubileuszowe ks. Antoniego Brzezińskiego - Pamiątka jubileuszu dwuchsetletniego Zgromadzenia XX. Filipinów na Górze Świętej Gostyńskiej Roku Pańskiego MDCCCLXVIII, t. I-II, Poznań 1869. Z obszernej literatury przedmiotu zob. np. H. Jaromin, Zarys historii Kongregacji Oratorium św. Filipa Neri w Polsce (1668-1968), „Nasza Przeszłość” 1970, t. XXXII, s. 5-143; K. Kuźmak, Maria Rosa Mystica. Sanktuarium na Świętej Górze Gostyńskiej. Dzieje i teologia, Gostyń 1988; Dom cudów Maryi 1512-2012. Pamiątka jubileuszu 500-lecia uznania cudów na Świętej Górze w Gostyniu, red. A. Adamski, J. Przybylski, M. Kulig, Święta Góra 2015.

${ }_{68}$ Zob. np. M.M. Kornacka, Rola Świętej Góry w życiu Edmunda Bojanowskiego, „Nasza Przeszłość” 1970, t. XXXII, s. 223-239.

${ }^{69}$ E. Bojanowski, Legenda o cudownej figurze Matki Boskiej Bolesnej na Świętej Górze Gostyńskiej, w: Prace, szkice i notatki Edmunda Bojanowskiego. Inedita, red. E. Gigilewicz, M.L. Opiela, t. I, Lublin 2016, s. 223-231.

${ }^{70}$ Tamże. Świadczą o tym również liczne odwołania do czytelnika, przyszłego odbiorcy tekstu, np.: „Ktokolwiek tedy będziesz odwiedzał Świętą Górę Gostyńską wejdź do otwartej podczas większych 
Nie został on jednak - o ile piszącemu te słowa wiadomo - nigdy wydany i do zeszłego roku spoczywał w archiwum w wersji rękopiśmiennej, choć końcowy fragment tej narracji został prawie dosłownie zacytowany w opracowaniu ks. A. Brzezińskiego ${ }^{71}$.

Wracając do artykułu Bojanowskiego z „Przyjaciela Ludu”, odnotujmy, że w kontekście reformacyjnego zamętu religijnego wspominał on też, poza obrazoburczymi ekscesami protestanckich właścicieli miasta związanymi ze Świętą Górą, o czasowym przejęciu gostyńskiej fary przez innowierców ${ }^{72}$.

W narracji na temat Świętej Góry autor wspomniał zamek właścicieli Gostynia, który mieścić się miał na wzgórzu nieopodal rynku. Ta lokalna tradycja była bardzo żywa, o czym świadczy fakt, że wzgórze to nazywane jest w Gostyniu „górą zamkową". Autor artykułu twierdził, że na sztucznie usypanym wzgórzu nieopodal rynku „rozdoły, kawałek sklepowego muru”, znajdowane tam „Zaśniedziałe tynfy i spróchniałe głowy trupie” świadczą o dawnej funkcji tego miejsca ${ }^{73}$. Kilka lat temu miały miejsce prace wykopaliskowe na Górze Zamkowej, które nie potwierdziły jednak istnienia tam murowanego zamku

uroczystości kapliczki”, „Otóż przy niniejszej książeczce masz wierny rysunek tej świętej figury...”, „A teraz słuchaj onej pobożnej wieści...”, „Patrz na ten obraz świętokradzkiego jej barbarzyństwa! Masz go wymalowany na lewej ścianie kapliczki”. Przywołane tu cytaty w większości odnoszą się do kapliczki przy drodze do bazyliki, która w XIX w. została odnowiona i ozdobiona wewnątrz freskami pędzla ks. Bernarda Preibisza, odnoszącymi się do podania o losach świętogórskiej piety. W słowach tych pada też wyraźna deklaracja, że tekst ten będzie częścią jakowejś „książeczki”. Miało to być wydawnictwo pobożnościowe, książeczka do nabożeństwa, ułożona przez E. Bojanowskiego, poprzedzona historycznym wstępem zawierającym miejscowe podanie. Praca nad jej publikacją była zaawansowana, gdyż w notatkach Bojanowskiego znajduje się kilka wersji schematów (planów, spisów treści), w których na początku znajduje się zawsze omawiana tu legenda - E. Bojanowski, Nabożeństwo do Matki Boskiej Bolesnej (schemat publikacji), w: Prace, szkice i notatki..., t. I, s. 811-814.

${ }^{71}$ Pod koniec tekstu legendy E. Bojanowski zapisał świadectwo o swoim uzdrowieniu, które wprowadził słowami: „Owóż i ten, co tę książeczkę dla was układał, doznał na tym świętym miejscu, jeszcze dzieckiem, cudu, kiedy już bliski skonania przez matkę poruczony tutaj Najświętszej Matki Bolesnej opiece wraz odzyskał zdrowie” - E. Bojanowski, Legenda o cudownej figurze..., s. 230. Ks. A. Brzeziński w swoim dziele (Pamiątka jubileuszu..., t. I, s. 283-284) umieścił opis tego cudu, niemal dosłownie go cytując. Cytat jego nie jest jednak do końca ścisły. Chcąc sprecyzować o kogo chodzi, zmienił fragment mówiący o tym, że srebrne oko opatrzności zostało ofiarowane „przez jedną matkę z okolicy tutejszej” na „ofiarowane około 1819 r. przez p. Teressę [sic!] z Umińskich Bojanowską z Grabonoga”. Ks. Brzeziński usprawiedliwiał się przed E. Bojanowskim z dokonanej zmiany w następujących słowach: „Swoje to własne uleczenie opisał tu, na nasze proźby, żyjący do dziś mąż, powszechnie szanowany, ale nie pozwolił swego nazwiska obwieścić; niechże wybaczy łaskawie, gdy swe pismo drukowane będzie czytał, żeśmy bez jego woli, poważyli się nazwisko matki przynajmniéj oznajmić wszystkim”. Na Świętej Górze musiał więc znajdować się opis cudu wyjęty z tekstu o gostyńskiej piecie albo cały ów tekst.

72 [E. Bojanowski], Do malowniczej podróży..., nr 27, s. 212. Por. J. Łukaszewicz, Krótki opis historyczny kościołów parochialnych, kościółków, kaplic, klasztorów, szkółek parochialnych, szpitali i innych zakładów dobroczynnych $w$ dawnej dyecezyi poznańskiej, t. II, Poznań 1859, s. 17.

73 [E. Bojanowski], Do malowniczej podróży..., nr 28, s. 222-223. 
z czasów nowożytnych ${ }^{74}$. Odnośnie tego miejsca wspomniana została także przez Bojanowskiego lokalna tradycja, w myśl której na gostyńskim zamku miała przebywać królowa Bona. Podanie to zostało jednak ocenione przez niego jako niewiarygodne ${ }^{75}$. Przywołane przez Bojanowskiego miejscowe legendy przypomniano $\mathrm{w}$ regionalnym piśmie $\mathrm{z}$ okresu międzywojennego $\mathrm{w}$ wersji ubarwionej opisem zapadnięcia się zamku złej właścicielki miasta ${ }^{76}$.

Z ważniejszych wydarzeń z przeszłości ziemi gostyńskiej Bojanowski wspomniał też o bitwie rosyjsko-pruskiej pod Gostyniem z 1761 r. - z czasów wojny siedmioletniej - po której pamiątką jest kula armatnia, która utkwiła w murze bazyliki świętogórskiej ${ }^{77}$. W artykule odnotowane zostało też stacjonowanie pod Gostyniem w 1665 r. wojsk królewskich wraz z królem Janem Kazimierzem w czasie rokoszu Lubomirskiego. „Może tu wtedy - przypuszcza Bojanowski - i nasz Pasek, nieodstępny towarzysz wyprawy królewskiej, dokazywał sobie i zażywał w Gostyniu wielkopolskich anguszków i tłustych gomółek"78. Wzmianki doczekał się również kościół w Strzelcach Wielkich, „gdzie nasz wieszcz Miaskowski spoczywa"79.

Sporo miejsca w swoim opisie Bojanowski poświęcił architekturze sakralnej, głównie gostyńskiej farze. Świątynia ta została także ukazana na rycinie dołączonej do artykułu ${ }^{80}$. Gostyń może oczywiście poszczycić się bardziej imponującym

${ }^{74} \mathrm{Na}$ temat istnienia zamku nie wypowiedział się w sposób kategoryczny J. Leśny (Najdawniejsza przeszłość (do poł. XV w.), w: Dzieje Ziemi Gostyńskiej, red. S. Sierpowski, Poznań 1979, s. 65, 85). W latach 2012-2014 archeolodzy z Muzeum Archeologicznego w Poznaniu przeprowadzili prace wykopaliskowe na Górze Zamkowej, w czasie których odkryli fundamenty budowli obronnej. Internetowe portale informowały o odkryciu ruin zamku: http://www.tvn24.pl/zdjecia/wykopaliskana-gorze-zamkowej-w-gostyniu,33713.html; http://wielkopolskie.naszemiasto.pl/artykul/galeria/ gora-zamkowa-w-gostyniu-to-nie-legendy-stal-tam-zamek,2000794,t,id.html; http://www.gostyn24. pl/Tajemnica_zostala_odkryta_\%20zdjecia,23685.html. [dostęp: 17.08.2017]. Jednak wbrew początkowym medialnym doniesieniom wykopaliska nie potwierdziły istnienia zamku z okresu nowożytnego, lecz drewnianej wieży mieszkalno-obronnej na kamiennym fundamencie, powstałej w XIII w., użytkowanej do połowy XIV w. Pozostałości późniejszego obiektu murowanego datowane są natomiast na XVIII w. Obiektów z XV-XVI w. nie znaleziono. Zostały być może zniszczone i zniwelowane w czasie późniejszych prac budowlanych. Wykopaliska na Górze Zamkowej w latach II wojny światowej prowadzili także Niemcy. Niedawne prace wykopaliskowe nie objęły jednak całego obszaru Góry Zamkowej ze względu na znajdujący się tam pomnik - B. Walkiewicz, Badania wykopaliskowe na Górze Zamkowej w Gostyniu, „Rocznik Gostyński” 2015, nr 2, s. 115-134.

75 [E. Bojanowski], Do malowniczej podróży..., nr 28, s. 223.

${ }^{76}$ C. Kędzierski, Legenda gostyńska, „Kronika Gostyńska” 1933, nr 8, s. 113-116.

77 [E. Bojanowski], Do malowniczej podróży..., nr 28, s. 222. O bitwie i kuli armatniej w ścianie bazyliki wspomina też Bojanowski w Dzienniku (t. I, s. 466). Szerzej na temat bitwy zob. M. Drozdowski, W dobie Rzeczpospolitej szlacheckiej (do 1793 r.), w: Dzieje Ziemi Gostyńskiej..., s. 139.

78 [E. Bojanowski], Do malowniczej podróży..., nr 28, s. 222. Chodzi tu oczywiście o Jana Chryzostoma Paska, autora głośnych Pamiętników.

79 Tamże.

${ }^{80}$ Jej autorem był, jak poinformował E. Bojanowski, gostyński aptekarz Józef Aleksander Rude. O jego grafice wspomina A. Hinc (Obraz dziejów ojczystych..., s. 311) za artykułem W. Stachowskiego 
zabytkiem architektury, czyli barokową bazyliką i klasztorem księży filipinów na Świętej Górze. Wydaje się jednak, że autor uznał Świętą Górę za miejsce dość powszechnie znane i chciał nieco spopularyzować drugą świątynię gostyńską. Jego bowiem zdaniem: „Tutejsza fara, jedna z piękniejszych u nas zabytków romantycznego budownictwa, uderza zaraz na pierwsze wejrzenie swoją niedzisiejszą prostotą i uprzejmością form architektonicznych [...] wszystko tu, choć nierozdrobnione [...] ni tak zbytecznie strzępiate, jak u staroniemieckich gmachów, łączy się przecież w poważną a gładko spływającą harmonią" ${ }^{81}$.

Będąc pod wrażeniem piękna gotyku, zauważył jednak Bojanowski w gostyńskiej farze pewne odstępstwa od kanonu tego stylu architektonicznego. Świadczy to o jego orientacji w zakresie sztuki i architektury. Stwierdził on mianowicie, że w gotyku środkowa nawa zazwyczaj jest wyeksponowana za pomocą wyższego niż $\mathrm{w}$ nawach bocznych dachu, $\mathrm{z}$ dodatkowym rzędem okien ponad niższymi bocznymi dachami. Natomiast w Gostyniu jeden dach pokrywa wszystkie trzy nawy. Brak dodatkowych okien powoduje, zdaniem Bojanowskiego, zbyt duże zaciemnienie wnętrza, które w gotyku jest normą, ale wynika raczej z przyciemnionych szyb w witrażach, a nie z braku okien, jak w przypadku gostyńskiej świątyni ${ }^{82}$. Autor miał też zastrzeżenia do sklepienia nawy głównej, które "nowsze i w guście niby włosko-francuzkim gładko zrobione, szpetnie odbija się od starych; pięknych i gałęzistych sklepień bocznych ganków", a ponadto „filary dźwigające środkową nawę, są zbyt grube i czworoboczne; a jako gotyckie, powinny być wysmukłe i choć nie gładko cylindrowe, jednak z wielu okrągłych słupków zestawione, jakby wiązki trzciny, aby się w górze nieznacznie schodziły gałęzistemi wzorami sklepienia" ${ }^{83}$. Autor opisu wspomniał też o kaplicy św. Anny z pięknymi sklepieniami i o jej fundatorze Makarym Skoczywlasie, garncarzu gostyńskim. Tę ostatnią wiadomość zaczerpnął on - jak informuje $\mathrm{w}$ przypisie $-\mathrm{z}$ archiwalnych dokumentów dotyczących wizytacji kościoła z 1777 r. Zatem jego artykuł nie jest tylko powierzchownym opisem, ale wiązały się z jego przygotowaniem także pewne badania źródłowe. Fundatora kaplicy

(Przyczynki do dziejów malarstwa w Gostyniu i okolicy, „Kronika Gostyńska” 1932, nr 6, s. 82-83). Do artykułu Bojanowskiego dołączony jest też plan sytuacyjny fary sporządzony przez autora artykułu lub J.A. Rudego.

${ }^{81}$ [E. Bojanowski], Do malowniczej podróży..., nr 27, s. 211. Wyrażenie „romantyczne budownictwo" zostało tu chyba użyte w sensie „średniowieczne”.

${ }_{82}$ Tamże.

${ }^{83}$ Tamże. Wygląd filarów nawy głównej tłumaczyć należy przebudową wnętrza świątyni po zniszczeniach z 1682 r. (być może pożar). Runęła wówczas południowa strona nawy z filarami. Gdy odbudowano sklepienie i filary, okazało się, że stare filary strony północnej nie wytrzymują ciężaru nowego, masywniejszego sklepienia. Dlatego poszerzono je od strony nawy głównej i wzmocniono śrubami. Stąd odmienność i nieforemność filarów oraz rażący Bojanowskiego, niepasujący do typowego gotyku, styl sklepienia nawy głównej - W. Kołomłocki, Wspomnienia z czasów odnawiania kościoła farnego w Gostyniu (Dokończenie), „Kronika Gostyńska” 1937, nr 12, s. 182. 
św. Anny i szpitala w Gostyniu wspominał też w swym regionalnym kompendium Edward Raczyński ${ }^{84}$.

Kilka zdań poświęcił też Bojanowski nagrobkom w posadzce prezbiterium, które były jednak zatarte i niewyraźne. Ciekawa jest uwaga autora odnośnie wieży kościelnej. Podaje on jej wysokość (136 stóp) wraz z przypuszczeniem o nieco innym wyglądzie pierwotnym: „[... [ nosi na wierzchu zębatą koronę; lecz ze strąconych jej narożników, szerszych na podstawie, niż inne dokoła zęby, wnoszę, że kiedyś miała cztery po rogach wieżyczki, jakie naprzykład są na wieżach westminsterskiego opactwa" ${ }^{85}$. Co do daty budowy fary nie znalazł Bojanowski precyzyjnej informacji, prócz wyrytego na drzwiczkach roku 1595, jednak był on przekonany, że kościół musiał powstać przed XVI stuleciem, „bo później, razem z upadkiem prawdziwie gotyckiej architektury w Niemczech, przestano i u nas gotyckie kościoły stawiać" ${ }^{66}$. Gostyńska fara cieszy się niesłabnącym zainteresowaniem miejscowych pasjonatów historii. Założyli oni w 2006 r. Towarzystwo Miłośników Gostyńskiej Fary, które m.in. animuje badania poświęcone świątyni i popularyzuje ich wyniki ${ }^{87}$.

Bojanowski zaprezentował Gostyń jako miejscowość, którą warto odwiedzić, chociażby ze względu na architekturę - możliwość podziwiania pięknych świątyń $\mathrm{w}$ dwóch bodajże najbardziej imponujących i reprezentacyjnych stylach, a więc gotyckim i barokowym. „Tutejsza stara fara gotycka i nowszy włoski klasztór Filipiński, z dziwnym odcieniem zestawiają obie te epoki budownictwa"s8. Autor artykułu nie używa w swym opisie terminu „barok”. Odnośnie bazyliki święto-

${ }^{84}$ E. Raczyński, Wspomnienia Wielkopolski..., niepaginowane strony przedmowy. Za Raczyńskim informację o fundacji kaplicy św. Anny przez gostyńskiego mieszczanina podaje Oskar Kolberg (Dzieła wszystkie, t. 10: Wielkie Księstwo Poznańskie, cz. II, Wrocław-Poznań 1982, s. 126). Szerzej o gostyńskim patrycjuszu Makarym (raczej Marcinie) Skoczywlasie i jego fundacji pisze S. Kozierowski (Dzieje Gostynia w średnich wiekach, odbitka z „Miesięcznika Kościelnego”, z 4 ilustracyami, Poznań 1913, s. 21-23).

${ }^{85}$ [E. Bojanowski], Do malowniczej podróży..., nr 27, s. 211. Okazuje się, że to przypuszczenie było słuszne, gdyż kierujący pracami gruntownej renowacji kościoła wspominał, że przy sposobności restauracji wieży stwierdzono, że na narożnikach musiały być kiedyś 4 wieżyczki, które spłonęły prawdopodobnie w czasie pożaru w 1682 r. - W. Kołomłocki, Wspomnienia z czasów odnawiania kościoła farnego w Gostyniu, „Kronika Gostyńska” 1937, nr 11, s. 176.

${ }^{86}$ [E. Bojanowski], Do malowniczej podróży..., nr 27, s. 212. Analizowany opis fary gostyńskiej został w całości zacytowany przez E. Raczyńskiego (Wspomnienia Wielkopolski..., s. 322), który także podaje, że nie sposób wskazać daty budowy kościoła: „zaginęły albowiem wszystkie akta, któryby nas w tej mierze oświecić mogły. Ktokolwiek przecież go widział wątpić zapewne nie będzie o jego starożytności”. Powstanie omawianej świątyni datuje się na przełom XIV i XV wieku - S. Kozierowski, Dzieje Gostynia w średnich wiekach..., s. 20. Co ciekawe, ksiądz Kozierowski, opisując wygląd świątyni, także cytuje artykuł E. Bojanowskiego z „Przyjaciela Ludu”. Józef Łukaszewicz, nie powołując się na żadną wzmiankę źródłową, podaje, że farę gostyńską wzniósł Bartosz Wezenborg z Gostynia w XV wieku - J. Łukaszewicz, Krótki opis historyczny..., t. II, s. 16-17.

${ }^{87}$ http://faragotykgostyn.pl/ [dostęp: 18.07.2017].

${ }^{88}$ [E. Bojanowski], Do malowniczej podróży..., nr 27, s. 212. 
górskiej posługuje się określeniem „styl włoski”" ${ }^{9}$.Z kilku wzmianek wnioskować można, że Bojanowski wyżej cenił walory gotyku niż baroku, o tym ostatnim pisząc jako o zepsutym smaku francuskim lub włoskim.

Kolejnym zagadnieniem, któremu autor artykułu poświęcił sporo miejsca, była kultura ludowa. Jako romantyczny folklorysta nie mógł pominąć tego zagadnienia. $\mathrm{W}$ jego ramach opisał postać ludowego rzeźbiarza oraz scharakteryzował lokalny strój biskupiański. Tzw. Biskupizna jest jednym z mikroregionów folklorystycznych Wielkopolski. Biskupianie (w literaturze próbowano też upowszechnić etnonim „Dzierżacy”, który jednak się nie przyjął) - chłopi z kilku wsi koło Krobi (terytorium dawnych parafii Krobia i Domachowo) wytworzyli specyficzną kulturę. Jej podstawą było silne poczucie odrębności i identyfikacja $z$ własną grupą $a^{90}$. Od średniowiecza do upadku Rzeczpospolitej szlacheckiej teren ten był własnością biskupów poznańskich, natomiast Krobia, do 1927 r., była ich letnią rezydencją. Stąd swą genezę bierze nazwa subregionu etnograficznego. Za sprawą urodzajnych ziem, mniejszych obciążeń feudalnych, a potem wczesnego uwłaszczenia tamtejsi chłopi wyróżniali się w okolicy stopniem zamożności. Wyrażał się on w specyficznym stroju, będącym jedną z ważniejszych odmian polskiego stroju ludowego. Po uwłaszczeniu Biskupianie stanowili najzamożniejszą grupę chłopską w Wielkopolsce. Bojanowski w następujący sposób opisał włościan z Biskupizny zjawiających się na gostyńskich jarmarkach końskich, które były wówczas słynne w całej Wielkopolsce: „W licznym zgiełku ujrzysz wtedy całe chłopstwo okoliczne [...] Serce się śmieje patrzeć tu na kmieci z krobskiej Biskupiny: co za pogoda w ich twarzach, co za mina i dostatek! Równych mało w okolicy, choć nasz wszystek lud od Szląska gospodarniejszy, niźli w innych stronach, nieustępuje drugim w narodowości" ${ }^{1}$.

Mimo swego uznania dla mieszkańców Biskupizny wynikającego z ich gospodarności, zamożności, zachowywania tradycji narodowych Bojanowski zauważył szybkie zmiany zachodzące w niektórych elementach ich tradycyjnej kultury. Dotyczyło to głównie stroju: „Niektóre przecież zmiany widzę w ubiorach

${ }^{89}$ Odwołuje się w ten sposób do geograficznego pochodzenia stylów, gdyż wielokrotnie stwierdza też, że gotyk to styl niemiecki, z krajów niemieckich.

90 Za wsie pierwotnie biskupiańskie uchodzą: Bukownica, Domachowo, Grabianowo, Chumiętki, Posadowo, Potarzyca, Rębowo, Sikorzyn, Stara Krobia, Sułkowice, Żychlewo. Trudno uchwycić relacje między nazwami „Dzierżacy” i „Biskupianie”. Ta pierwsza jest o wiele starsza. Próbuje się ją wywodzić z XIII-wiecznego, wojskowego osadnictwa drobnorycerskiego i wolnych chłopówdzierżawców na terenie pogranicza. W XIX wieku etnonim ten był już anachroniczny (zakładając, że wcześniej był adekwatny i używany), o czym świadczy także to, że Bojanowski o nim nie wspomniał. Por. L. Gomolec, Wielkopolskie grupy regionalne i lokalne nazwy ludności wiejskiej, w: Kultura ludowa Wielkopolski, red. J. Burszta, t. 2, Poznań 1964, s. 12, 17, 28-32; S. Kozierowski, Ziemia Gostyńska ws świetle nazw geograficznych i najdawniejszych źródeł średniowiecza, nadbitka z „Kroniki Gostyńskiej”, Gostyń 1930, s. 37-38.

${ }^{91}$ [E. Bojanowski], Do malowniczej podróży..., nr 27, s. 211. 
tutejszych od lat kilkunastu; szerokich pasów skórzanych, czerwonem suknem podszytych, nienoszą już dzisiajsi chłopi; a u kobiet, zamiast używanych dawniej, czerwonych lub błękitnych pończoch $\mathrm{z}$ różnobarwnemi klinami po bokach, lub białych z czerwonemi wrabianiami, widać tylko same białe. U modrych sukien przestają już także chłopi tutejsi nosić czerwone wyłogi, a kobiety różnowzorowemi sycami zastępują piękne, a teraz już rzadsze, spodniki białe z czerwonemi prążkami, których czeskie wieśniaczki, mimo dawności obcego wpływu, dotąd niezaniechały dla barw narodowych, które z niemi mamy wspólne" 92 .

Ten krótki opis stroju biskupiańskiego i jego przemian stanowił później podstawowe, jedyne w zasadzie, źródło dla etnografów, badaczy polskiego stroju ludowego. Na omawiany artykuł powołuje się w swoim studium Adam Glapa, główny badacz tego zagadnienia. Ustalił on, że charakterystyka zamieszczona w krajoznawczym artykule w „Przyjacielu Ludu” z 1839 r. jest pierwszym znanym opisem stroju dzierżackiego (biskupiańskiego) ${ }^{93}$. Fakt ten każe widzieć w Bojanowskim prekursora badań nad Biskupizną. Był on pierwszym autorem, który zasygnalizował specyfikę, odmienność tego regionu. Jako pierwszy w literaturze, piśmiennictwie użył też pojęcia „Biskupianie”. S. Jankowiak, autor zestawienia bibliograficznego na temat Biskupizny, nie stwierdził, aby wcześniej ktokolwiek posłużył się w tekstach pisanych tym pojęciem ${ }^{94}$.

Jednocześnie warto zwrócić uwagę, jak w swoich ludoznawczych zainteresowaniach i badaniach Bojanowski był nowatorski i nieszablonowy. W epoce romantycznego zbieractwa folklorystycznego nie zwracano uwagi na kulturę materialną ludu, preferując kulturę umysłową. Wszyscy zbierali pieśni, podania, powiastki, klechdy, przysłowia, nie rejestrując np. wyglądu stroju i chat ${ }^{95}$.

92 Tamże. Drugi pod względem chronologicznym opis stroju ludowego z Biskupizny znajduje się u Oskara Kolberga (Dzieła wszystkie, t. 10, cz. II, s. 155-159).

93 A. Glapa, Strój dzierżacki, „Atlas Polskich Strojów Ludowych” 1953, cz. II: Wielkopolska, z. 2, s. 8-9, 19, 24. Autor ten traktuje omawiany artykuł jako anonimowy, nie podaje nawet jego tytułu, odsyłając w przypisach tylko do rocznika leszczyńskiego czasopisma i strony. Jego własna charakterystyka stroju biskupiańskiego jest streszczeniem tekstu Bojanowskiego. Zob. też inne opracowania A. Glapy, np. Ubiór chłopski, w: Kultura ludowa Wielkopolski..., t. 1, Poznań 1960, s. 510. Natomiast autorzy licznych wydawanych w ostatnich latach popularyzatorskich publikacji albumowych nie wdają się w historyczne subtelności i przemiany stroju ludowego, prezentując jego wersję o wiele późniejszą, lepiej udokumentowaną, XX-wieczną - zob. np. E. Piskorz-Branekova, Strój Biskupiański, w tejże: Polskie stroje ludowe, Warszawa 2003, s. 68-73.

94 S. Jankowiak, Wstęp, w: Biskupizna. Dzieje regionu, folklor biskupiański, jego popularyzacja i popularyzatorzy. Zestawienie bibliograficzne, Krobia 1993, s. 8. Dodać należy, że cytowane wyżej słowa Bojanowskiego na temat tego jak to „serce się śmieje patrzeć tu na kmieci z krobskiej Biskupizny” S. Jankowiak użył w charakterze motta do bibliografii.

${ }^{95}$ [jk - J. Krzyżanowski], Folklorystyka polska, w: Słownik folkloru polskiego, red. J. Krzyżanowski, Warszawa 1965, s. 110. Także prekursor romantycznej folklorystyki - Zorian Dołęga Chodakowski pomijał w swych badaniach kulturę materialną ludu i nie doceniał jej, zainteresowania swoje zwracając ku kulturze duchowej, wytworom ludowej wyobraźni i fantazji - J. Maślanka, Zorian Dołęga Chodakowski. Jego miejsce w kulturze polskiej i wplyw na polskie piśmiennictwo romantyczne, 
Tymczasem Bojanowski nie pomijał tego typu etnograficznej problematyki w swoich ludoznawczych poszukiwaniach. Wspomniane wyżej przemiany zachodzące w ludowym stroju biskupiańskim interpretował on ponadto jako przejaw szybkiego zanikania tradycyjnej kultury ludowej w Wielkopolsce. Podobne obserwacje zanotowali inni badacze folkloru wielkopolskiej wsi ${ }^{96}$. Sytuacja ta była zapewne związana z końcem epoki feudalnego zamknięcia, odseparowania środowiska wiejskiego od zewnętrznych wpływów. W Wielkopolsce przeobrażenia kultury ludowej następowały najszybciej, gdyż tu najwcześniej doszło do uwłaszczenia chłopów (regulacje rozpoczęły się w 1823 r.). Zaakcentowanie przez E. Bojanowskiego zanikania dawnych, tradycyjnych elementów kultury materialnej wielkopolskiego ludu wpisać też można w charakterystyczną dla XIX-wiecznego podróżopisarstwa tendencję. Badacz tego nurtu piśmiennictwa stwierdził bowiem, że romantyczni podróżnicy prezentowali zazwyczaj rzeczywistość odchodzącą w przeszłość, skazaną na zagładę, przedstawianą w atmosferze wielkich pożegnan ${ }^{97}$.

Tradycje lokalnej kultury ludowej, wyrażające się w obrzędowości, zwyczajach, stroju, muzyce są obecnie kultywowane i energicznie popularyzowane na terenie Biskupizny. Powstaje w związku z tym wiele publikacji ${ }^{98}$. Uchylając się od ich przytaczania, piszący te słowa chciałby podkreślić zasługi autorów z okresu międzywojennego, którzy rejestrowali i popularyzowali współczesną sobie kulturę ludową mieszkańców okolic Krobi ${ }^{99}$.

Drugim aspektem folklorystycznej, w zasadzie etnograficznej, tematyki artykułu Bojanowskiego jest przedstawienie postaci ludowego twórcy - Walentego z Grabonoga. Wiadomości o jego życiu i twórczości czerpał autor zapewne $\mathrm{z}$ tradycji miejscowej. Nie podał żadnych bliższych dat poza stwierdzeniem,

Wrocław-Warszawa-Kraków 1965, s. 56-57. Podobnie Oskar Kolberg - autor otwierający krytycznonaukowy okres polskiej folklorystyki - początkowo nie wykazywał zainteresowania wobec kultury materialnej mieszkańców wsi, dopiero stopniowo dochodząc do przekonania, że przejawy kultury duchowej i umysłowej mają oczywisty związek z materialnymi warunkami bytowania. Zob. np. R. Górski, Oskar Kolberg. Zarys życia i działalności, Warszawa 1970, s. 241-242; A. Skrukwa, Oskar Kolberg 1814-1890, Poznań 2014, s. 60-65.

96 J.J. Lipiński, Piosnki ludu wielkopolskiego, cz. I, Poznań 1842, s. V-VIII; Ł. Puślecki, „Przedmowa” do zbioru „Pieśni ludu wielkopolskiego” Franciszka Wawrowskiego - próba edycji, w: Studia bibliologicznoedytorskie. Edycje. Prasa. Czytelnictwo (analizy - materiały - przeglady), red. K. Grabias-Banaszewska, R. Sztyber, Zielona Góra 2015, s. 104. Por. Ł. Puślecki, Wielkopolskie programy badań..., s. 97-118.

${ }_{97}$ S. Burkot, Polskie podróżopisarstwo..., s. 375-377. O tym jak szybko zmieniała się w jego czasach wielkopolska kultura ludowa pisał też Bojanowski w Dzienniku (t. I, s. 46, 190-191, 195, 525).

${ }_{98}$ Zob. np. Biskupizna. Ziemia - Tradycja - Tożsamość, red. A.W. Brzezińska, M. Machowska, Krobia 2016.

${ }^{99}$ Dotyczy to nie tylko lokalnych periodyków typu „Kronika Gostyńska” czy „Ziemia Gostyńska”, ale także pism wielkopolskich i ogólnopolskich. Dokonano też wtedy pierwszych nagrań dźwiękowych, nakręcono krótkometrażowe filmy. Wśród wielu autorów na wyróżnienie zasługuje Jan Bzdęga z Domachowa - zob. bibliografię Biskupizna. Dzieje regionu... 
że w Grabonogu przed kilkudziesięciu laty żył sławny chłop-rzeźbiarz ${ }^{100}$. Zatem czas jego działalności należy usytuować w II połowie XVIII wieku. Należał on do biedniejszej warstwy ludności wiejskiej. Jego talent miał ujawnić się przypadkowo, gdy wypełniając sobie czas spędzany na pastwisku, wyrzeźbił w kamieniu figurkę Matki Boskiej. Próba była na tyle udana, że rzeźbę wystawiono na słupie przy drodze. Walenty został później pomocnikiem malarza, który malował ściany w miejscowym dworze. Przy tej okazji „popróbowawszy pędzla” ujawnił swoje zdolności do malarstwa obrazowego. Jego talent, zdaniem Bojanowskiego, sprawił, że przyjęto go do służby przy klasztorze filipinów na Świętej Górze, gdzie miał malować „Z dziwnym talentem i uderzającą trafnością podobieństw” olejne obrazy, głównie o tematyce religijnej oraz portrety ${ }^{101}$. Do czasów autora artykułu zachował się tylko portret proboszcza filipińskiego wiszący w bibliotece klasztornej (zaginął on potem w czasie II wojny światowej). Sportretowanym przez ludowego twórcę superiorem filipinów był ks. Jakub Ostrowski ${ }^{102}$.

Walentym z Grabonoga zajmowali się badacze wielkopolskiej twórczości ludowej. Traktuje się go jako ludowego twórcę działającego w znanym sanktuarium, będącym miejscem odwiedzin licznych pątników. Na ich użytek malował on obrazy treści religijnej, na które było spore zapotrzebowanie. Wzmianka o działalności twórczej Walentego przy sanktuarium na Świętej Górze jest dowodem istnienia ludowego obraźnictwa odpustowego w tym miejscu wcześniej niż w znanych sanktuariach na Jasnej Górze w Częstochowie i w Kalwarii Zebrzydowskiej ${ }^{103}$. Jak wspomniano już, Walenty z Grabonoga znany był także jako rzeźbiarz. Bojanowski wymienił jego dzieła - figurę świętego Benona, stojącą w Grabonogu na posesji krewnych rzeźbiarza oraz „Bożą Mękę”, stojącą na zachodnim skraju wsi. Jego zdaniem „obie te rzeźby odznaczają się szlachetnym

100 [E. Bojanowski], Do malowniczej podróży..., nr 28, s. 223.

101 Tamże.

102 Ciekawą okolicznością jest fakt, że ks. J. Ostrowski był kapłanem, który w 1814 r. udzielał chrztu Edmundowi Bojanowskiemu. Ks. Ostrowski był członkiem kongregacji filipinów w Gostyniu. W 1792 i 1795 r. wybierany był na przełożonego wspólnoty. Jednak w 1797 r. złożył on urząd i wystąpił ze zgromadzenia, zostając księdzem diecezjalnym i proboszczem w Strzelcach Wielkich - H. Jaromin, Zarys historii Kongregacji..., s. 34; Archiwum parafialne w Strzelcach Wielkich, Liber Baptisatorum, a. 1814, nr 120, w: Beatificationis et canonizationis Servi Dei Edmundi Bojanowski, viri laici, fund. Congreg. Ancillarum B.M.V. IMM. (1814-1871). Positio super virtutibus ex officio concinnata, vol. I, Romae 1996, s. 15.

103 S. Błaszczyk, Plastyka, w: Kultura ludowa Wielkopolski, red. J. Burszta, t. 1, Poznań 1960, s. 607. W dodatku Walenty z Grabonoga był autentycznym twórcą ludowym, zaś działający w XIX w. w Częstochowie i Kalwarii malarze reprezentowali typ malarstwa rzemieślniczego, przeszli przeszkolenie warsztatowe i byli raczej zawodowymi malarzami. Na poparcie tezy, iż Walenty był malarzem specjalizującym się w obrazach religijnych, S. Błaszczyk powołuje się na księgi kościelne z przełomu XVIII i XIX wieku, w których ludowy twórca nazywany jest kilka razy łacińskim określeniem „pictor” (malarz) - S. Błaszczyk, Rzeźbiarze ludowi południowej Wielkopolski, „Polska Sztuka Ludowa” 1958, nr 1. 
układem i pilnem wypracowaniem, przedewszystkiemi, jakie w kościołach wiejskich i na polnych słupach widzieć można"104. W ogrodzie grabonoskiego majątku znajdował się również wykonany przez Walentego słup kompasowy zdobiony arabeskami, który „zadziwiłby każdego miłośnika rzeźby”105. Do rzeźb autorstwa Walentego, poza świętym Benonem i krzyżem w Grabonogu, dodać należy św. Benona w Starej Krobi, wyrzeźbionego w żywym pniu drzewa oraz przydrożne figury św. Rozalii w Grabonogu i Chrystusa Frasobliwego w Sie$\mathrm{dlcu}^{106}$. Całość opowiadania o ludowym rzeźbiarzu skwitował Bojanowski uwagą o talentach, które rodzą się pod wiejską strzechą: „Jakimże to mistrzem mógł się był stać nasz chłopek, gdyby był zagraniczne muzea pozwiedzał i ćwiczył się pod okiem prawdziwych sztukmistrzów. Ale tak to może niejeden talent marnieć u nas musi bez wszelkiej poręki”107.

Ta krótka notka o ludowym artyście z Grabonoga stała się podstawą i pierwszym źródłem wiedzy dla wszystkich późniejszych regionalistów oraz badaczy zajmujących się tym zagadnieniem. W ukazującym się w okresie międzywojennym gostyńskim czasopiśmie regionalnym pojawił się artykuł o Walentym z Grabonoga, stanowiący w większości przedruk tekstu „nieznanego autora $\mathrm{w}$ «Przyjacielu Ludu»" ${ }^{108}$. Rękodzielnicze dzieła Walentego, które przetrwały do tamtych czasów, nie spotkały się z tak daleko idącymi, jak u Bojanowskiego, zachwytami nad talentem ludowego twórcy. Obraz z klasztoru filipinów został scharakteryzowany jako „robota bardzo słaba, daleka od talentu, o jakim wspomina kronikarz - jak na samouka z ludu na te czasy wystarczająca", natomiast jedna z rzeźb ,aczkolwiek prymitywna - okazuje cechy bezsprzecznego talentu, któremu brak wyszkolenia"109. Władysławowi Kołomłockiemu - gostyńskiemu nauczycielowi z okresu międzywojennego, twórczość Walentego wydawała się nadzwyczaj "prymitywna” ${ }^{110}$. Świadczy to tym bardziej o tym, jak dużym wyczuciem, świadomością wykazał się Bojanowski. Wiedział, jak właściwie ocenić wartość ludowej sztuki, na którą przedstawiciele warstw wykształconych jeszcze długie dziesięciolecia nie zwracali żadnej uwagi lub wręcz nią pogardzali.

104 [E. Bojanowski], Do malowniczej podróży..., nr 28, s. 223.

105 Tamże.

106 S. Błaszczyk, Kapliczka ludowa z Grabonoga, „Studia Muzealne” 1957, nr 3, s. 124-137.

107 [E. Bojanowski], Do malowniczej podróży..., nr 28, s. 223.

108 W.Kołomłocki, O Walentymz Grabonoga, artyściezBożejŁaskisłów kilka, „Kronika Gostyńska” 1929, nr 4, s. 1-6. Autor dołączył też do artykułu rysunki przedstawiające rzeźby Walentego, które wykonał Wacław Boratyński, uczeń gostyńskiego gimnazjum, później grafik i malarz - P. Michałowski, Boratyński Wacław (1908-1939), w: Wielkopolski słownik biograficzny..., s. 71-72.

109 W. Kołomłocki, O Walentym z Grabonoga..., s. 5-6.

110 Fakt, że jakieś dzieło uznane zostało za „prymitywne” przez ludzi stosujących w swych ocenach kryteria adekwatne dla sztuki profesjonalnej, artystycznej jest dla badaczy dowodem na jego typowo ludowy rodowód pozbawiony elementów szkolenia warsztatowego twórcy - S. Błaszczyk, Plastyka..., s. 606. 
Określenie sposobów oceny i wartościowania sztuki ludowej nastąpiło właściwie dopiero w XX wieku. Dziś Walenty z Grabonoga traktowany jest jako jeden z najwybitniejszych twórców ludowych Wielkopolski. Posiadaniem jego rzeźby szczyci się na swojej stronie internetowej Muzeum Etnograficzne w Poznaniu ${ }^{111}$.

Wartości poznawcze artykułu E. Bojanowskiego, żywy i obrazowy tok opowiadania, ciekawe i atrakcyjne ujęcie tematu przeszłości i obecnego stanu ziemi gostyńskiej stały się przesłanką późniejszych przedruków tego tekstu. W XIX wieku było ich kilka. Pierwszy pojawił się jeszcze w tym samym 1839 r., w królewiackim czasopiśmie „Muzeum Domowe albo Czytelnia Wieczorna. Dzieło poświęcone historyi, statystyce, moralności, naukom i literaturze krajowej”112. Kolejny przedruk umieścił w swym historycznym opracowaniu Wspomnienia Wielkopolski Edward Raczyński. Wielkopolski arystokrata nie pokusił się o własne badania, lecz stwierdził „odwołujemy się w tym względzie do opisu tego miasteczka umieszczonego w dzienniku pod tytułem «Przyjaciel Ludu»"113. Następny, świadczący o wartości artykułu, przedruk pojawił się w dziele Oskara Kolberga Lud. Jego zwyczaje, sposób życia, mowa, podania, przysłowia, obrzędy, gusła, zabawy, pieśni, muzyka i tańce. Słynny etnograf, charakteryzując rejon gostyński, także stwierdził: „Przytaczamy wyjątek z opisu miasta Gostynia (Przyjaciel ludu, Leszno 1839, rok V. Nr 27-8, a za nim Muzeum domowe, Warszawa 1839, T.2. Str. 5), jako dobrze w ogóle malujący stan miast tej okolicy w owej epoce"114.

\section{Podsumowanie}

Powyżej piszący te słowa niejeden raz udowadniał niebagatelną poznawczą i naukową wartość analizowanych tu artykułów Edmunda Bojanowskiego o K. Miaskowskim oraz historii i zabytkach Gostynia. Tym, co na koniec wypada jeszcze raz podkreślić, jest ich wybitnie pionierski charakter - odkrycie zapomnianego poety, pierwsze w piśmiennictwie użycie nazwy „Biskupianie”

${ }^{111} \mathrm{http}: / /$ www.mnp.art.pl/oddzialy/muzeum-etnograficzne/zbiory/ [dostęp: 19.08.2017]. Warto nadmienić, że zachowały się do dzisiaj dwie rzeźby Walentego z Grabonoga - św. Rozalia w Muzeum Etnograficznym w Poznaniu i św. Benon w Muzeum im. Edmunda Bojanowskiego w Grabonogu.

${ }_{112}$ b.a., Gostyń. Miasteczko w Wielkim Księstwie Poznańskim, „Muzeum Domowe” 1839, t. 2, s. 5-16.

${ }^{113}$ E. Raczyński, Wspomnienia Wielkopolski..., t. 1, s. 326. Cytat z artykułu zamieszczony został w dwóch częściach - jedną stanowi opis wyglądu i teraźniejszego stanu miasta na stronach 326-329, drugą opis gostyńskiej fary na stronach 322-324.

114 O. Kolberg, Dzieła wszystkie, t. 10, cz. II, s. 362. Siedem tomów Ludu... dotyczących Wielkiego Księstwa Poznańskiego ukazało się w latach 1875-1882. Całość spuścizny Kolberga została opracowana i wydana przez Polskie Towarzystwo Ludoznawcze jako Dzieła Wszystkie Oskara Kolberga. Wielkopolskie serie $L u d u$... zostały w nich przedrukowane w tomach 9-15. 
i charakterystyka ich stroju, pierwszy znany w literaturze opis twórczości wielkopolskiego ludowego rzeźbiarza. Owa pionierskość wynika też z ciekawej okoliczności. Otóż Bojanowski w swoich naukowych poszukiwaniach wykazał się niebywałą intuicją, albo raczej świadomością badawczą, podejmując i popularyzując tematy i zagadnienia, które jego współczesnych nie interesowały, były zapomniane, lekceważone i dopiero po jego tekście lub zgoła wiele lat później docenione ${ }^{115}$. Jego teksty były też atrakcyjnie napisane - tematyka krajoznawcza, która mogła zaciekawić czytelnika ujęta w bardzo dobrej, potoczystej narracji. Świadczą o tym liczne przedruki dwóch omówionych tu artykułów, chociażby w czasopismach wychodzących w zaborze rosyjskim, w Kongresówce. Redakcje czasopism unikają bowiem praktykowania przedruków - artykuły Bojanowskiego musiały być więc tego warte.

Znaczenie Bojanowskiego w zakresie przywrócenia pamięci o poecie K. Miaskowskim jest dość znane. Inaczej rzecz się ma z jego niewątpliwie wyjątkową i prekursorską rolą w rozwoju gostyńskiego regionalizmu historycznego. Wynika to $\mathrm{z}$ tego, że $\mathrm{w}$ odróżnieniu od tekstu o Miaskowskim nie podpisał on swego artykułu o Gostyniu, publikując go anonimowo. To pierwsze opracowanie regionalistyczne, dotyczące ziemi gostyńskiej, dla wielu autorów było podstawowym źródłem wiedzy. Do dziś gostyńscy regionaliści - a w ponadregionalnym aspekcie etnografowie i historycy - powołują się na artykuł Do malowniczej podróży po Wielko-Polsce, Gostyń i jego okolica jako na tekst anonimowy ${ }^{116}$. Nie można się temu jednak dziwić, skoro nawet autorzy zajmujący się badaniem poszczególnych elementów dorobku naukowego E. Bojanowskiego nie mają świadomości, że tekst ten jest jego autorstwa ${ }^{117}$. W związku $\mathrm{z}$ tą anonimową

115 Owe szczęśliwe odkrycia Bojanowskiego - chodziło wówczas o K. Miaskowskiego - Stanisława Chociej (Twórczość literacka..., s. 173) skomentowała w następujący sposób: „Ten niezmiernie pracowity, niezmordowany wprost człowiek, potrafił zawsze znaleźć w swoim otoczeniu coś, co by mogło zainteresować jego ziomków".

116 Jednym $\mathrm{z}$ najnowszych, typowych przykładów tego stanu rzeczy jest artykuł prof. Rafała Witkowskiego na temat sanktuarium na Świętej Górze - R. Witkowski, Momenty przełomowe w dziejach sanktuarium maryjnego na Świętej Górze pod Gostyniem, w: Dom cudów Maryi 1512-2012. Pamiątka jubileuszu 500-lecia uznania cudów na Świętej Górze w Gostyniu, red. A. Adamski, J. Przybylski, M. Kulig, Święta Góra 2015, s. 19.

117 J. Fogel, Błogosławiony Edmund Bojanowski (1814-1871) jako amator archeologii regionalnej. Fragment starożytnictwa w Wielkim Księstwie Poznańskim, „Folia Praehistorica Posnaniensia” 2011, t. XVI, s. 11-33. Przywołany tu autor, omawiając archeologiczny artykuł Bojanowskiego Żalki z pod Gostynia..., nawiązuje do interesującego nas artykułu Do malowniczej podróży..., w którym także była mowa o prehistorycznych cmentarzyskach. Nie zdając sobie sprawy z tego, że E. Bojanowski był autorem obu tych tekstów, stwierdził, że miał on jakiegoś anonimowego poprzednika w dziele badania grabonoskich żalników. W tym kontekście autor artykułu pragnie usprawiedliwić się z niepodjęcia w swoim tekście tematyki archeologicznej, która była jednym z zagadnień poruszonych przez E. Bojanowskiego w krajoznawczym szkicu o Gostyniu i okolicy. Wynika to z jednej strony $\mathrm{z}$ tego, że istnieje już opracowanie na ten temat autorstwa archeologa prof. Jerzego Fogla. Z drugiej strony podjęcie kolejnego zagadnienia rozbudowałoby zbytnio ramy objętościowe niniejszego 
publikacją, będącą efektem ówczesnego zwyczaju lub nadmiernej skromności autora (którą nieraz byli skłonni wypominać mu jego współcześni) E. Bojanowski nie został należycie doceniony jako pierwszy gostyński regionalista i prekursor lokalnych badań etnograficznych. W związku z tym istotnym postulatem jest upowszechnienie tej wiedzy. Piszący te słowa ma nadzieję, że niniejszy artykuł spełni w jakiejś mierze to zadanie.

\section{Bibliografia}

\section{Prasa}

„Gazeta Codzienna” (Warszawa)

"Gazeta Wielkiego Księstwa Poznańskiego" (Poznań)

„Muzeum Domowe” (Warszawa)

„Przyjaciel Ludu" (Leszno)

"Tygodnik llustrowany" (Warszawa)

„Tygodnik Literacki” (Poznań)

\section{Źródła drukowane}

Baliński M., Lipiński T., Starożytna Polska pod względem historycznym, jeograficznym i statystycznym, t. I, Warszawa 1885.

Beatificationis et canonizationis Servi Dei Edmundi Bojanowski, viri laici, fund. Congreg. Ancillarum B.M.V. IMM. (1814-1871). Positio super virtutibus ex officio concinnata, vol. I, Romae 1996.

Bojanowski E., Dziennik, wydanie kompletne rękopisu i luźnych kartek Dziennika wraz z zapisami dziennymi Ochronka Podrzecza 1851-1854 i relacją s. Elżbiety Szkudłapskiej Ostatnie dnie życia i pogrzeb, objaśnił, skomentował i wstępem poprzedził L. Smołka, t. I-IV, Wrocław 2009.

Bojanowski E., Korespondencja Edmunda Bojanowskiego z lat 1829-1871, objaśnił, skomentował i zarysem monograficznym poprzedził L. Smołka, t. 1-2, Wrocław 2001.

Hoffmanowa K., Opis różnych okolic Królestwa Polskiego, t. 1: Z widokiem Puław, Wrocław 1833.

Kolberg O., Dzieła wszystkie, t. 10: Wielkie Księstwo Poznańskie, cz. II, Wrocław-Poznań 1982.

Lipiński J.J., Piosnki ludu wielkopolskiego, cz. I, Poznań 1842.

Łukaszewicz J., Krótki opis historyczny kościołów parochialnych, kościółków, kaplic, klasztorów, szkółek parochialnych, szpitali i innych zakładów dobroczynnych w dawnej dyecezyi poznańskiej, t. II, Poznań 1859.

Maciejowski W.A., Piśmiennictwo polskie od czasów najdawniejszych aż do roku 1830, t. 1-2 Warszawa 1851-1852.

Prace, szkice i notatki Edmunda Bojanowskiego. Inedita, red. E. Gigilewicz, M.L. Opiela, t. I-II, Lublin 2016.

Puślecki Ł. „, Przedmowa” do zbioru "Pieśni ludu wielkopolskiego" Franciszka Wawrowskiego - próba edycji, w: Studia bibliologiczno-edytorskie. Edycje. Prasa. Czytelnictwo (analizy-materiały - przeglądy), red. K. Grabias-Banaszewska, R. Sztyber, Zielona Góra 2015.

Raczyński E., Wspomnienia Wielkopolski to jest województw poznańskiego, kaliskiego i gnieźnieńskiego, t. 1-2, Poznań 1842-1843.

artykułu. Wydaje się, że jest to materiał na osobny tekst, zważywszy, że pewne twierdzenia J. Fogla wymagałyby weryfikacji. 
Rymarkiewicz J., Wiadomość o życiu i pismach Kaspra Miaskowskiego, w: Zbiór rythmów Kaspra Miaskowskiego znowu przez autora poprawionych, rozszerzonych i na dwie części podzielonych, w Poznaniu w drukarni J. Rossowskiego roku 1622, teraz do druku po raz trzeci podany, przejrzany, objaśniony i wiadomościq̨ o życiu i pismach Miaskowskiego opatrzony przez J. Rymarkiewicza.... t. 1-2, Poznań 1855.

Syrokomla W., Wycieczki po Litwie w promieniach od Wilna (Troki, Stokliszki, Jezno, Funie, Niemiez, Miedniki etc.), z ryciną litografowaną i drzeworytami, Wilno 1857.

Złota księga, w której zawarte sa przykłady cnót chrześcijańskich ludziom ku nauce izabawie, Lwów 1861.

\section{Literatura}

Błaszczyk S., Kapliczka ludowa z Grabonoga, „Studia Muzealne” 1957, nr 3.

Błaszczyk S., Plastyka, w: Kultura ludowa Wielkopolski, red. J. Burszta, t. 1, Poznań 1960.

Błaszczyk S., Rzeźbiarze ludowi południowej Wielkopolski, „Polska Sztuka Ludowa” 1958, nr 1.

Brzeziński A., Pamiątka jubileuszu dwuchsetletniego Zgromadzenia XX. Filipinów na Górze Świętej

Gostyńskiej Roku Pańskiego MDCCCLXVIII, t. I-II, Poznań 1869.

Burkot S., Polskie podróżopisarstwo romantyczne, Warszawa 1988.

Chociej S., Twórczość literacka i działalność wydawnicza Edmunda Bojanowskiego, "Nasza Przeszłość" 1967, t. XXVI.

Drozdowski M., W dobie Rzeczpospolitej szlacheckiej (do 1793 r.), w: Dzieje Ziemi Gostyńskiej, red. S. Sierpowski, Poznań 1979.

Fogel J., Błogosławiony Edmund Bojanowski (1814-1871) jako amator archeologii regionalnej. Fragment starożytnictwa w Wielkim Księstwie Poznańskim, „Folia Praehistorica Posnaniensia” 2011, t. XVI.

Glapa A., Strój dzierżacki, „Atlas Polskich Strojów Ludowych” 1953, cz. II: Wielkopolska, z. 2.

Glapa A., Ubiór chłopski, w: Kultura ludowa Wielkopolski, red. J. Burszta, t. 1, Poznań 1960.

Gomolec L., Wielkopolskie grupy regionalne i lokalne nazwy ludności wiejskiej, w: Kultura ludowa Wielkopolski, red. J. Burszta, t. 2, Poznań 1964.

Górski R., Oskar Kolberg. Zarys życia i działalności, Warszawa 1970.

Hernas C., Barok, Warszawa 1973.

Hinc A., Obraz dziejów ojczystych w pozaszkolnej edukacji historycznej społeczeństwa polskiego w Wielkim Księstwie Poznańskim w pierwszej połowie XIX wieku, Poznań 2007.

Jakóbczyk W., Prasa polska w Wielkopolsce w latach 1832-1858, w: Prasa polska w latach 1661-1864, red. J. Łojek, t. 1, Warszawa 1976.

Janion M., Żmigrodzka M., Romantyzm i historia, Gdańsk 2001.

Jankowiak S., Biskupizna. Dzieje regionu, folklor biskupiański, jego popularyzacja i popularyzatorzy. Zestawienie bibliograficzne, Krobia 1993.

Jankowiak S., Edmund Bojanowski 1814-1871. Życie i działalność. Bibliografia, Grabonóg 1995.

Jankowiak S., Kasyno Gostyńskie (1835-1846). U początków pracy organicznej w Wielkopolsce, Gostyń 1996.

Jarochowski K., Literatura poznańska w pierwszej połowie bieżacego stulecia, Poznań 1884.

Jaromin H., Zarys historii Kongregacji Oratorium św. Filipa Neri w Polsce (1668-1968), „Nasza Przeszłość" 1970, t. XXXII.

Kamionka-Straszakowa J., „Do ziemi naszej”. Podróże romantyków, Kraków 1988.

Karwowski S., Czasopisma wielkopolskie, cz. I: 1796-1859, Poznań 1908.

Kędzierski C., Legenda gostyńska, "Kronika Gostyńska” 1933, nr 8.

Kieniewicz S., Społeczeństwo polskie w powstaniu poznańskim 1848 roku, Warszawa 1960.

Kochlerówna A., Biblioteka Poznańskiego Towarzystwa Przyjaciół Nauk 1857-1957, „Roczniki Historyczne" 1957, R. XXIII. 
Kołomłocki W., O Walentym z Grabonoga, artyście z Bożej Łaski słów kilka, „Kronika Gostyńska” 1929, nr 4.

Kołomłocki W., Wspomnienia z czasów odnawiania kościoła farnego w Gostyniu, „Kronika Gostyńska" 1937, nr 11, 12.

Kornacka M.M., Rola Świętej Góry w życiu Edmunda Bojanowskiego, „Nasza Przeszłość” 1970, t. XXXII.

Kosmanowa B., Biblioteki polskie w Wielkim Księstwie Poznańskim, Poznań 1982.

Kozierowski S., Dzieje Gostynia w średnich wiekach, odbitka z „Miesięcznika Kościelnego”, z 4 ilustracyami, Poznań 1913.

Kozierowski S., Ziemia Gostyńska w świetle nazw geograficznych i najdawniejszych źródeł średniowiecza, nadbitka z „Kroniki Gostyńskiej”, Gostyń 1930.

Leśny J., Najdawniejsza przeszłość (do poł. XV w.), w: Dzieje Ziemi Gostyńskiej, red. S. Sierpowski, Poznań 1979.

Majątki Wielkopolskie, t. I: Powiat Gostyński, red. J. Skuratowicz, Szreniawa 1997.

Maślanka J., Zorian Dołęga Chodakowski. Jego miejsce w kulturze polskiej i wpływ na polskie piśmiennictwo romantyczne, Wrocław-Warszawa-Kraków 1965.

Molik W., Etos Wielkopolan w historycznym rozwoju i oglądzie społecznym. Wprowadzenie do problematyki antologii, w: Etos Wielkopolan. Antologia tekstów o społeczeństwie Wielkopolski z drugiej połowy XIX i XX wieku, wyb. i oprac. W. Molik, Poznań 2005.

Niewolak-Krzywda A., Poeta wewnętrznych niepokojów - Kasper Miaskowski, w: Pisarze staropolscy. Sylwetki, red. S. Grzeszczuk, t. 2, Warszawa 1997.

Nieznanowski S., O poezji Kaspra Miaskowskiego. Studium o kształtowaniu się baroku w poezji polskiej, Lublin 1965.

Pakowska R., Polskie przekłady poematów Byrona "Childe Harold" i „Manfred", Kraków 1938.

Pieścikowski E., „Ach! W tym Poznańskiem..." Życie literackie XIX wieku, Poznań 2003.

Piskorz-Branekova E., Polskie stroje ludowe, Warszawa 2003.

Puślecki Ł., Fascynacja i edukacja. Program badań folklorystycznych Edmunda Bojanowskiego jako system wymiany intelektualnej, w: Dziedzictwo myśli pedagogicznej Edmunda Bojanowskiego we współczesnej edukacji w Polsce i na świecie, red. M.L. Opiela, Lublin 2014.

Puślecki Ł., O etapie literacko-naukowym w biografii Edmunda Bojanowskiego, "Scripta Comeniana Lesnensia. Miscellanea" 2010, nr 8.

Puślecki Ł., Wielkopolskie programy badań folklorystycznych w pierwszej połowie XIX wieku, „Studia Zachodnie" 2015, t. 17.

Sienkiewicz H., Kasper Miaskowski. (Studyum literackie), w: Pisma Henryka Sienkiewicza nieobjęte wydaniem zbiorowem, cz. 1: Pisma młodociane. Mikołaj Sęp Szarzyński. Kasper Miaskowski, Warszawa 1904.

Skrukwa A., Oskar Kolberg 1814-1890, Poznań 2014.

Słownik folkloru polskiego, red. J. Krzyżanowski, Warszawa 1965.

Stachowski W., Przyczynki do dziejów malarstwa w Gostyniu i okolicy, "Kronika Gostyńska” 1932, nr 6. Strumiłło D., Z dziejów zbieractwa wielkopolskiego XIX w. Kasyno w Gostyniu - Przyjaciel Ludu -Zwiqzek Zbieraczy Starożytności Krajowych w Szamotułach, „Muzealnictwo” 1958, nr 7/8.

Tabor S., Krótki zarys historji cudownego obrazu Matki Boskiej Świętogórskiej, „Kronika Gostyńska” $1931, \mathrm{nr} 2$.

Walkiewicz B., Badania wykopaliskowe na Górze Zamkowej w Gostyniu „,Rocznik Gostyński” 2015, nr 2. Wielkopolski słownik biograficzny, Warszawa-Poznań 1981.

Wierzbicki A., Historiografia polska doby romantyzmu, Wrocław 1999.

Witkowski R., Momenty przełomowe w dziejach sanktuarium maryjnego na Świętej Górze pod Gostyniem, w: Dom cudów Maryi 1512-2012. Pamiątka jubileuszu 500-lecia uznania cudów na Świętej Górze w Gostyniu, red. A. Adamski, J. Przybylski, M. Kulig, Święta Góra 2015.

Wojtkowski A., Biblioteka Kasyna Gostyńskiego, „Kronika Gostyńska” 1933, nr 10.

Wysocka B., Kultura literacka Wielkopolski w latach 1919-1939, Poznań 1990. 
Żalik A., Współpraca Edmunda Bojanowskiego z „Przyjacielem Ludu”, w: Sługa Boży Edmund Bojanowski i jego troska o człowieka. Materiały z Il sympozjum, Grabonóg 1991.

\section{Streszczenie}

Autor prezentuje w artykule dorobek Edmunda Bojanowskiego w zakresie historycznych badań regionalnych, skupiając się na jego tekstach dotyczących regionu, z którego on sam pochodził, czyli ziemi gostyńskiej. Chodzi tu o dwa ważne dla badań regionalnych artykuły: Kasper Miaskowski oraz Do malowniczej podróży po Wielko-Polsce, Gostyń i jego okolica. W pierwszym z nich Bojanowski wydobył z zapomnienia postać wybitnego poety, co zainspirowało wielu autorów do dalszego badania biografii i twórczości Miaskowskiego. Artykuł o Gostyniu i okolicy jest, utrzymanym w konwencji podróżopisarskiej, opisem krajoznawczym. Ten niezwykle ciekawy i poruszający wiele zagadnień tekst do dziś jest jednym z podstawowych źródeł do badania historii subregionu gostyńskiego. Analizowane tu artykuły pozwalają uznać E. Bojanowskiego za prekursora regionalnych badań historycznych, dotyczących ziemi gostyńskiej. O jakości tych tekstów świadczą też ich liczne przedruki.

Słowa kluczowe: Edmund Bojanowski, regionalizm historyczny, subregion gostyński.

\section{Edmund Bojanowski as a researcher of history of region}

\section{Summary}

This article presents works of Edmund Bojanowski about historical research of region. The author focused on those of Bojanowski's texts, which were related to the region Gostyń Land where he came from. Two articles which are very important for regional research were analysed: Kasper Miaskowski and Do malowniczej podróży po Wielko-Polsce. Gostyń i jego okolica. In the first article he reminds the figure of distinguish poet that inspired many authors to the further research of the biography and work of Miaskowski. Article about Gostyń and its area is touringdescription kept in travel literature style. This extremely interesting and raising many of the issues text is still one of the main sources for the history of Gostyń region. The articles which are analysed here make it possible to consider E. Bojanowski as a precursor of regional study of history concerning Gostyń Land. Numerous reprints are evidence of the quality of these texts.

Keywords: Edmund Bojanowski, historical regionalism, Gostyń region. 